\title{
Disaggregating Real Exchange Rate Dynamics: A Structural Approach
}

\author{
Punnoose Jacob* \\ Ghent University
}

March 14, 2011

\begin{abstract}
This paper employs a small open economy DSGE model, estimated over 19862009, to decompose the dynamic influence of domestic and international prices on the Canada-US real exchange rate. While the real exchange rate mimics the dynamic behavior of the relative price of non-tradables in terms of tradables in response to a non-tradable sector-specific disturbance, the purely tradable component dominates in the case of other shocks, irrespective of their structural origin. Variance decompositions reveal that the sources of the movements in the tradable component lie in unsystematic deviations from uncovered interest parity as well as import price mark-up shocks. Consequently, these disturbances are far more potent than internal tradable or non-tradable sector-specific disturbances in driving real exchange rate fluctuations.

JEL classification: C11, F41

Keywords: New Open Economy Macroeconomics, Small Open Economy, NonTradables, Canada-US Real Exchange Rate, Bayesian Estimation.
\end{abstract}

*Address: Department of Financial Economics, Ghent University, Woodrow Wilsonplein 5D, Ghent, Belgium B9000. Email: Punnoose.Jacob@Ugent.be. A previous version of this paper was circulated as 'The Dynamic Interplay between Relative Prices and the Real Exchange Rate: Structural Evidence'. I acknowledge financial support from the Inter-University Attraction Poles Program-Belgium Science Policy (Contract Number P6/07) and the Flemish Fund for Scientific Research (FWO). I also thank Nicholas Groshenny, Robert Kollmann, Vivien Lewis, Gert Peersman, Ine Van Robays, Roland Straub and Raf Wouters for helpful suggestions. All remaining errors are mine. 


\section{Introduction}

The profession has generally struggled to relate the persistent and volatile behavior of the real exchange rate to macroeconomic fundamentals. Key to understanding the real exchange rate are its multiple constituents: the nominal exchange rate as well as the domestic and international relative prices. Traditional theorists viewed the movements in the real exchange rate as shifts in the relative price of non-tradable goods to that of tradable goods (Samuelson 1964). However, more recently, economists have appealed to the price of tradable goods, i.e. deviations from the law of one price in particular, to explain real exchange rate movements (See e.g. Betts and Devereux 2000). This paper makes an empirical contribution to this classic debate.

Extant empirical analyses of the nexus between the real exchange rate and relative prices have relied on a statistical decomposition of the in-sample volatility of the real exchange rate into that of its various components. Engel (1999) decomposes the variance of the CPI-based US real exchange rate vis-à-vis many of its trade-partners and observes that almost none of the variability emanates from the relative price of non-tradables. Chari, Kehoe and McGrattan (2002) attribute as much as 98 percent of the variance of the Euro-Dollar real exchange rate to the international relative price of tradables. These reduced-form results have motivated a generation of general equilibrium models of the exchange rate, e.g. Chari, Kehoe and McGrattan (2002), to abstract from non-tradables. More recently, Wolden Bache, Næss and Sveen (2009) explicitly introduce export and import prices into the definition of the real exchange rate and find that the wedge between these prices at the border and the price of domestically tradable goods, i.e. deviations from the law of one price, contribute between 30 and 70 percent of the variance of four US bilateral real exchange rates while the non-tradable component always contributes below 10 percent.

However, recent empirical studies have provided evidence in favor of the importance of the relative price of non-tradable goods for the real exchange rate. Burstein, Eichenbaum and Rebelo (2006) find that the non-traded component accounts for about half the variability of the real exchange rate. Betts and Kehoe (2008), in an extensive study of 50 economies over 25 years, attribute a third of the variance of the real exchange rate to the relative price of non-tradables. These results suggest that the open-economy literature, more specifically the empirical general equilibrium models that study the important 
sources of exchange rate fluctuations (e.g. Lubik and Schorfheide 2006, Bergin 2006 and Rabanal and Tuesta 2010), may have been premature in abandoning fully articulated non-tradable sectors.

In the light of the inconclusive evidence provided by the reduced-form literature, we offer a structural treatment of real exchange rate fluctuations, by embedding the exchange rate in a richly specified dynamic stochastic general equilibrium (DSGE) model that allows it to fluctuate in response to deviations from the law of one price as well as changes in the relative price of non-tradables. Subsequently, we use full-information methods to fit the DSGE model on time series on a battery of domestic and international price series that constitute the real exchange rate. The central contribution of this paper is a study of the correspondence between the real exchange rate and its constituent relative prices in dynamic responses to structural shocks. Complementary to the reduced-form studies, we recover the dominant relative price effect, but unlike that literature, we distinguish between the movements that are generated in the relative prices, and hence the aggregate real exchange rate due to the distinct structural origin of these disturbances. ${ }^{1}$

Our results are in the direction of those reported by Engel (1999) and Wolden Bache et al. (2009). In all the variants of the estimated DSGE model, we find that while the real exchange rate inherits the dynamic behavior of the internal relative price of nontradables in response to a technology shock specific to the non-tradable sector, movements in the purely tradable component dictate real exchange rate dynamics in the case of other disturbances, irrespective of their structural origin. Not surprisingly, sector-specific disturbances hardly matter in the larger scheme: the shock to the uncovered interest parity condition, that exerts its influence via the purely tradable component, accounts for about half the variability whenever it is used in the estimation exercise. In fact, even when we do not employ this shock in the estimation, internal sector-specific shocks do not matter for the forecast variance. Price mark-up shocks in the import segment of the model appear to be more potent than shocks to internal prices in generating fluctuations in the real exchange rate.

The model that we build and estimate is in the new tradition of open-economy models

\footnotetext{
${ }^{1}$ It is important to understand that we examine the impulse responses and the forecast variance of the real exchange rate while the statistical studies decompose the variance of the real exchange rate into the variances and covariances of its defined components, typically the international relative price of tradables and the internal relative price of non-tradables.
} 
estimated with Bayesian methods as seen in Justiniano and Preston (2006), Jacob and Peersman (2008) and Rabanal and Tuesta (2010). Unlike these models, in view of our objective, we introduce a non-tradable sector in our DSGE model as in two empirical papers which study real exchange rate dynamics in stylized two-country models linking the US and the Euro-Area. Rabanal and Tuesta (2007) and Cristadaro, Gerali, Neri and Pisani (2008) evaluate the ability of standard empirical open-economy models, augmented with non-tradables, to address fundamental macroeconomic puzzles as the real exchange rate volatility and persistence anomaly and the consumption real-exchange rate anomaly, together with understanding the important stochastic driving forces of the real exchange rate. $^{2}$

Rabanal and Tuesta (2007) find that technology shocks in the non-tradable sector determine a third of the conditional forecast variance of the Euro-Dollar real exchange rate. However, their results rest uncomfortably on two unrealistic features of the economic environment they construct: the imposition of strict uncovered interest parity and the law of one price for tradable goods. The first feature - the presence of the parity condition that ties down the expected evolution of the nominal exchange rate to the interest differential - obscures the fact that the exchange rate is mostly driven by stochastic deviations from uncovered interest parity, as the vast majority of the empirical open-economy literature finds (See e.g. Rabanal and Tuesta 2010 and Justiniano and Preston 2006). On the other hand, under the law of one price, export and import prices are simply foreign currency equivalents of the price of the domestic tradable good and there is perfect passthrough of exchange rate fluctuations into import prices. This strategy precludes the use of export and import prices, which are typically more volatile than domestic prices, in the estimation of their model and hences ignores the possibility of these prices acting as potential sources of volatility for the real exchange rate as reported by Wolden Bache et al. (2009). The second study closely related to ours is that of Cristadoro, Gerali, Neri and Pisani (2008) who impose neither pure uncovered interest parity nor the law of one price in their empirical model. In extreme contrast to Rabanal and Tuesta (2007), they find that about ninety percent of the asymptotic forecast variance of fluctuations in the Euro-Dollar exchange rate are driven by deviations from interest parity. However, just as Rabanal and Tuesta (2007), they continue to ignore import and export price series in their empirical analysis.

\footnotetext{
${ }^{2}$ Recent theoretical models that use non-tradable goods to address exchange rate puzzles include Benigno and Thoenissen (2008), Dotsey and Duarte (2008) and Corsetti, Dedola and Leduc (2008).
} 
While our DSGE model shares the introduction of a non-tradable sector with both papers, and uses endogenous deviations from the law of one price as in Cristadoro et al. (2008), the focus on the inter-linkages between the relative prices distinguishes this paper from its precedents. Furthermore, instead of studying the synthetic Euro-Dollar series in a stylized two-country model as in the two aforementioned papers, we examine the CanadaUS real exchange rate in a small open economy (SOE) model. This modelling strategy delivers a statistical advantage: unlike Rabanal and Tuesta (2007) and Cristadoro et al. (2008), all the prices that can influence the real exchange rate, i.e. the prices of domestic tradable and non-tradable goods, foreign price level as well as bilateral variables as the nominal exchange rate and export and import prices, can be treated as observable states in the estimation while preserving the tractability of the exercise. ${ }^{3}$ We can also allow for a much richer specification of the home economy, Canada in our case, while the larger and relatively closed foreign economy that forms the second country, the US, is modelled in a minimalist way. We fit the SOE model on twelve macroeconomic quarterly time series over 1986-2009.

To the extent that the SOE model is estimated with Canada-US data, this paper is also related to the work of Justiniano and Preston (2006, 2010) and Dib (2003) who estimate more stylized SOE models on similar datasets. The former examines the influence of foreign shocks on the SOE while the latter compares macroeconomic dynamics under closed economy and open-economy assumptions. In contrast to the focus of this paper, these studies do not dwell on the components of the real exchange rate. In this manner, we contribute simultaneously to two strands of the literature, the modern empirical general equilibrium open-economy literature as well as the reduced-form literature on the influence of relative prices on the exchange rate.

We proceed as follows. Section 2 outlines a SOE model that endogenously determines the international and internal prices that constitute the real exchange rate. Section 3 details the disaggregation of the real exchange rate and discusses the qualitative differences in the influences of its component prices. Section 4 presents the estimation results while Section 5 evaluates the robustness of the main results. Section 6 concludes.

\footnotetext{
${ }^{3}$ While Rabanal and Tuesta (2007) only use aggregate CPI and PPI (domestic tradables) series, Cristadoro et al. (2008) use the goods as well as services components of the CPI. As empirical two-country models typically employ an equal number of series for each economy along with bilateral series as the exchange rate, both studies ignore the export-import price series as well as physical investment to preserve tractability.
} 


\section{The Baseline Small Open Economy Model}

The baseline model has much in common with the closed economy models estimated for the US and the Euro-Area by Smets and Wouters (2003, 2007). The open-economy dimension of the model is very similar to that of Adolfson et al. (2007) who estimate a rich SOE model for Sweden. All these models have enjoyed considerable success in terms of statistical fit. We only present equilibrium conditions for the SOE that are log-linearized around a simple symmetric non-stochastic steady-state with balanced trade and no inflation or exchange rate depreciation. Variables presented as logarithmic deviations from the steady-state are denoted by a superscript ' ’'. Typically, foreign economy variables and parameters are denoted with a superscript '*', We follow Smets and Wouters (2003) in abstracting from balanced growth and normalizing all the shocks in the theoretical model so that they enter the estimation with a unit coefficient. The structural innovations in all the $\operatorname{AR}(1)$ shock processes, $\eta^{x}$ are i.i.d. $N\left(0, \sigma_{x}\right)$ and the autocorrelation coefficients are indicated by $\rho_{x} \in[0,1) \forall x$.

Aggregation Sectors Production takes place in three layers in the SOE. The bottom layer is composed of two monopolistically competititive sectors producing the nontradable bundle $Y^{N T}$ and the home-produced tradable bundle $Y_{H}^{T}$. The middle layer is formed by a perfectly competitive sector that aggregates the home-produced tradable bundle and the imported bundle $Y_{M}^{T}$ to compose a final tradable good $Y^{T}$ in a CES combination, very similar to the Armington aggregation of home and imported tradables seen in Backus, Kydland and Kehoe (1994). $\xi_{M}$ denotes the share of imports in the final tradable aggregate. The top layer is constituted by a perfectly competitive sector that combines the non-tradable bundle and the tradable aggregate again in a CES composite to form the final good $Y$ for consumption and investment. $\xi_{N T}$ denotes the share of non-tradable component absorbed by the SOE. The final consumption-investment good is not traded internationally.

The aggregate price level $P^{C P I}$, i.e. the consumer price index, is a convex combination of price of the non-tradable bundle $P^{N T}$ and that of the final tradable aggregate $P^{T}$. On the other hand, the price level of the tradable aggregate combines the price of the domestic tradable bundle $P_{H}^{T}$ and the price of the imported bundle $P_{M}^{T}$.

$$
\hat{P}_{t}^{C P I}=\left(1-\xi_{N T}\right) \hat{P}_{t}^{T}+\xi_{N T} \hat{P}_{t}^{N T}
$$




$$
\hat{P}_{t}^{T}=\left(1-\xi_{M}\right) \hat{P}_{H t}^{T}+\xi_{M} \hat{P}_{M t}^{T}
$$

$\mu_{N T}>0$ denotes the elasticity of substitution between the non-tradable bundle and the tradable aggregate and $\mu_{M}>0$ denotes the trade elasticity. These parameters moderate the relationship between the relative prices and the corresponding quantities through the demand functions for the aggregated intermediate bundles.

$$
\begin{gathered}
\hat{Y}_{t}^{T}=\hat{Y}_{t}+\mu_{N T} \xi_{N T}\left(\hat{P}_{t}^{N T}-\hat{P}_{H t}^{T}\right) \\
\hat{Y}_{t}^{N T}=\hat{Y}_{t}^{T}-\mu_{N T}\left(\hat{P}_{t}^{N T}-\hat{P}_{H t}^{T}\right) \\
\hat{Y}_{H t}^{T}=\hat{Y}_{t}^{T}+\mu_{M} \xi_{M}\left(\hat{P}_{M t}^{T}-\hat{P}_{H t}^{T}\right) \\
\hat{Y}_{M t}^{T}=\hat{Y}_{H t}^{T}-\mu_{M}\left(\hat{P}_{M t}^{T}-\hat{P}_{H t}^{T}\right)
\end{gathered}
$$

To be sure, there are numerous ways of introducing non-tradables into a DSGE model. For example, in their theoretical model Dotsey and Duarte (2008) devise an intricate input-output structure where non-tradable final output enters two segments of the model, unlike in our case. Firstly, it is used as an input to produce the final tradable aggregate, which is partly used for investment while the remaining enters the final consumption bundle. Secondly, non-tradables are also a direct input in the consumption bundle to form the final good. ${ }^{4}$ Given our objective to estimate the model, the simple productionbased structure that we employ is less restrictive on the data as it economizes on the model-implied steady-state shares $\left(e . g . \xi_{M}, \xi_{N T}\right)$ which are typically calibrated. This is in contrast to a richer specification which allows for different shares of non-tradables and imports in consumption and investment and entails a multiplicity of share parameters that have to be fixed. ${ }^{5}$ An additional advantage of this simple specification lies in the tradable segment as we avoid making a distinction between consumption and investment

\footnotetext{
${ }^{4}$ In another theoretical study, Benigno and Thoenissen (2008), the final good which has a non-tradable component, is only used for consumption. The intermediate non-tradable and tradable goods firms that own the capital stocks use a proportion of their output as investment in their production process in the next period. On the other hand, in the empirical literature, Rabanal and Tuesta (2007) use only a final consumption bundle that combines tradable and non-tradable components. The output of both intermediate sectors that is not consumed is absorbed by fiscal spending shocks. In Cristadoro et al. (2008) non-tradables appear both in the form of distribution services and are part of the final composite for consumption. Unlike the theorists, the latter two studies abstract from investment.

${ }^{5}$ As DSGE models are usually estimated with demeaned data, the filtered data is not informative about these long-run share parameters and most empirical modellers prefer to calibrate these shares from sample averages.
} 
export-import prices. Empirically, this is useful as the export-import price data that we use to estimate the model cover a wide variety of investment as well as consumption goods ranging over agricultural products, machinery, oil and automobiles. On the downside, the simplicity of the structure necessitates abstracting from distribution services, a form of expenditure on the non-tradable sector found to be important to understand real exchange rate behavior in theoretical models, e.g. Corsetti and Dedola and Leduc (2008). ${ }^{6}$

Intermediate Sectors The two intermediate goods sectors in the SOE are monopolistically competitive, with the aggregated non-tradable and tradable bundles being Dixit-Stiglitz composites of a continuum of differentiated intermediate varieties. Each intermediate variety can be both consumed and invested and the distinction between varieties between the two sectors lies only in the tradability. In each sector indexed by $z \in\{T, N T\}$, output is produced by a Cobb-Douglas function that combines labor and capital rented from the household, with $\alpha$ governing the share of capital. $\varepsilon^{z}$ is an $\operatorname{AR}(1)$ sector-specific productivity disturbance and $f c$ is a fixed cost in production necessary to ensure that profits are zero in steady-state.

$$
y_{t}^{z}=f c\left(\alpha \hat{K}_{t-1}^{z}+(1-\alpha) \hat{N}_{t}^{z}+\varepsilon_{t}^{z}\right)
$$

The factors of production are perfectly mobile and hence their respective prices, the (CPI-based) real rates $r^{k}$ and $w$ are equalized across sectors. This implies the real marginal costs $(1-\alpha) \hat{w}+\alpha \hat{r}^{k}-\varepsilon^{z}$ are identical, except for the sector-specific technological disturbances.

Nominal adjustment is imperfect in both sectors and price-setting behavior is governed by Calvo lotteries. $\theta^{N T} \in(0,1)$ is the Calvo probability parameter for the sales of nontradables while $\iota^{N T} \in[0,1]$ denotes the degree of price indexation. If $\beta \in(0,1)$ denotes the agent's subjective discount factor and $\mathbf{E}_{t}$ is the expectational operator conditional on the information set at the beginning of period $t$, the Phillips curve for sales by the

\footnotetext{
${ }^{6}$ The presence of distribution services combined with a very low elasticity of substitution between home-produced tradables and imports, can be used to generate high real exchange rate volatility and lowpassthrough. However, Rabanal and Tuesta (2007) report that the presence of this friction reduces the empirical fit of their Euro-Area-US model considerably.
} 
non-tradable sector is given by

$\hat{\pi}_{t}^{N T}=\frac{\iota^{N T}}{1+\beta \iota^{N T}} \hat{\pi}_{t-1}^{N T}+\frac{\beta}{1+\beta \iota^{N T}} \mathbf{E}_{t} \hat{\pi}_{t+1}^{N T}+\frac{\left(1-\beta \theta^{N T}\right)\left(1-\theta^{N T}\right)}{\theta^{N T}\left(1+\beta \iota^{N T}\right)}\left[(1-\alpha) \hat{w}_{t}+\alpha \hat{r}_{t}^{k}-\varepsilon_{t}^{N T}+\hat{P}_{t}^{C P I}-\hat{P}_{t}^{N T}\right]$

On the other hand, $\theta_{H}^{T} \in(0,1)$ is the Calvo parameter for domestic sales of the tradable good while $\iota_{H}^{T} \in[0,1]$ denotes the degree of price indexation for domestic sales. The Phillips curve for domestic sales is given by

$\hat{\pi}_{H t}^{T}=\frac{\iota_{H}^{T}}{1+\beta \iota_{H}^{T}} \hat{\pi}_{H t-1}^{T}+\frac{\beta}{1+\beta \iota_{H}^{T}} \mathbf{E}_{t} \hat{\pi}_{H t+1}^{T}+\frac{\left(1-\beta \theta_{H}^{T}\right)\left(1-\theta_{H}^{T}\right)}{\theta_{H}^{T}\left(1+\beta \iota_{H}^{T}\right)}\left[(1-\alpha) \hat{w}_{t}+\alpha \hat{r}_{t}^{k}-\varepsilon_{t}^{T}+\hat{P}_{t}^{C P I}-\hat{P}_{H t}^{T}\right]$

The international trade structure of the SOE is adapted from Adolfson et al. (2007). The monopolistic importer buys foreign output at the domestic currency equivalent of the aggregate foreign price level $P^{C P I *}$ and sells it in the SOE in the local currency as a mark-up over the procurement price, generating a wedge between the import price facing the final good sector and the cost of imports. This wedge expressed as $\hat{P}^{C P I *}+\widehat{N E x}-\hat{P}_{M}$ can be interpreted, as in Lubik and Schorfheide (2005), as the law of one price gap. If $\theta_{M}^{T} \in(0,1)$ is the Calvo parameter for import sales and $\iota_{M}^{T} \in[0,1]$ denotes the degree of price indexation, the imports Phillips curve is given by

$\hat{\pi}_{M t}^{T}=\frac{\iota_{M}^{T}}{1+\beta \iota_{M}^{T}} \hat{\pi}_{M t}^{T}+\frac{\beta}{1+\beta \iota_{M}^{T}} \mathbf{E}_{t} \hat{\pi}_{M t}^{T}+\frac{\left(1-\beta \theta_{M}^{T}\right)\left(1-\theta_{M}^{T}\right)}{\theta_{M}^{T}\left(1+\beta \iota_{M}^{T}\right)}\left[\hat{P}_{t}^{C P I *}+\widehat{N E x_{t}}-\hat{P}_{M t}+\varepsilon_{M t}^{P M}\right]$

The presence of price-stickiness dampens the transmission of fluctuations in the nominal exchange rate $N E x$ (a rise in which implies a depreciation of the SOE currency) into import prices and hence the aggregate price level of the SOE. $\varepsilon_{M}^{P M}$ is an $\operatorname{AR}(1)$ cost-push shock to import price inflation and can be motivated by time-varying demand elasticities facing the importer in the SOE. In effect, it acts the exogenous component of the law of one price gap.

Export sales of the SOE constitute only an infinitesimal proportion of total absorption in the foreign economy. $Y^{*}$ and $P^{C P I *}$ indicate foreign output and consumer price levels, the demand function for exports is given by

$$
\hat{Y}_{H t}^{* T}=\hat{Y}_{t}^{*}-\mu_{M}\left(\hat{P}_{H t}^{* T}-\hat{P}_{t}^{C P I *}\right)
$$

Analagous to the importer, the representative exporter sets his price $P_{H t}^{* T}$ in the foreign currency as a mark-up over its nominal marginal cost, the price of the home-produced 
tradable good. If $\theta_{H}^{* T} \in(0,1)$ is the Calvo parameter for export sales and $\iota_{H}^{* T} \in[0,1]$ denotes the degree of price indexation, the corresponding Phillips curve is given by

$\hat{\pi}_{H t}^{* T}=\frac{\iota_{H}^{* T}}{1+\beta \iota_{H}^{* T}} \hat{\pi}_{H t-1}^{* T}+\frac{\beta}{1+\beta \iota_{H}^{* T}} \mathbf{E}_{t} \hat{\pi}_{H t+1}^{* T}+\frac{\left(1-\beta \theta_{H}^{* T}\right)\left(1-\theta_{H}^{* T}\right)}{\theta_{H}^{* T}\left(1+\beta \iota_{H}^{* T}\right)}\left[\hat{P}_{H t}^{T}-\widehat{N E x_{t}}-\hat{P}_{H t}^{* T}+\varepsilon_{H t}^{* P M}\right]$

where $\varepsilon_{H t}^{* P M}$ is a cost-push shock to export price inflation and as in the importer's case, it can be motivated by time-varying demand elasticities facing the exporter in the foreign market.

Consumers Consumers have access to private risk-free nominal one-period bonds that are denominated either in domestic or foreign currency and the domestic physical capital stock to facilitate the inter-temporal transfer of wealth. Equation 13 determines the flow of consumption that is indicated by $C$. The curvature parameter $\sigma_{C}>0$ and the external habit coefficient $\vartheta \in[0,1)$ govern the inter-temporal elasticity of substitution. $R$ is the gross interest rate on domestic bonds set by the monetary authority while $\pi^{C P I}$ is the gross inflation in the consumer price index. $\varepsilon^{T I}$ is a disturbance that can be interpreted as a 'time-impatience' shock to the subjective discount factor and evolves as AR(1) process.

$$
\hat{C}_{t}=\frac{1}{1+\vartheta} \mathbf{E}_{t} \hat{C}_{t+1}+\frac{\vartheta}{1+\vartheta} \hat{C}_{t-1}-\frac{1}{\sigma_{C}} \frac{(1-\vartheta)}{(1+\vartheta)}\left(\hat{R}_{t}-\mathbf{E}_{t} \hat{\pi}_{t+1}^{C P I}\right)+\varepsilon_{t}^{T I}
$$

Equation 14 presents uncovered interest parity (UIP), the arbitrage condition for home and foreign bonds that pins down the expected depreciation of the domestic currency to the differential in nominal interest rates. Since the failure of UIP in its primitive form has been well documented, we add to this condition an $\operatorname{AR}(1)$ stochastic process $\varepsilon^{U I P}$. Devereux and Engel (2002) attribute this random deviation from strict interest parity as a source of exchange rate disconnect from fundamentals and interpret it as emanating from misaligned expectations from foreign currency traders on the evolution of the currency. Farrant and Peersman (2006) present vector autoregression evidence on the importance of 'pure exchange rate' shocks in driving OECD exchange rates. In a DSGE environment, a pure exchange rate shock can easily be understood as a disturbance to the interest parity condition. When we estimate the model, the UIP shock captures the persistence in the nominal exchange rate data that we cannot match in its absence given that interest parity predicts that the exchange rate behaves in a purely forward-looking manner. Finally, due to the incomplete asset markets set-up, $\kappa>0$ that measures the cost incurred by SOE 
investors in acquiring net foreign assets $N F A$, is used as a stationarity-inducing device. ${ }^{7}$

$$
\mathbf{E}_{t} \widehat{N E x}_{t+1}-\widehat{N E x}_{t}=\hat{R}_{t}-\left(\hat{R}_{t}^{*}-\kappa \widehat{N F A}_{t}+\varepsilon_{t}^{U I P}\right)
$$

The consumer invests a quantity $I$ of the final good in the aggregate capital stock $K$ that is rented out to both the non-tradable and tradable sectors as factor inputs. Investment is subject to adjustment costs increasing in the parameter $\psi>0$ that delays its response to changes in its marginal value measured by Tobin's Q.

$$
\begin{gathered}
\hat{I}_{t}=\frac{\beta}{1+\beta} \mathbf{E}_{t} \hat{I}_{t+1}+\frac{1}{1+\beta} \hat{I}_{t-1}+\frac{1}{\psi(1+\beta)} \widehat{T Q}_{t}+\varepsilon_{t}^{I N V} \\
\hat{K}_{t}=\delta \hat{I}_{t}+(1-\delta) \hat{K}_{t-1}+\delta \psi(1+\beta) \varepsilon_{t}^{I N V} \\
\widehat{T Q}_{t}=(1-\beta(1-\delta)) \mathbf{E}_{t} \hat{r}_{t+1}^{k}+\beta(1-\delta) \mathbf{E}_{t} \widehat{T Q}_{t+1}-\left(\hat{R}_{t}-\mathbf{E}_{t} \hat{\pi}_{t+1}^{C P I}\right)
\end{gathered}
$$

$\varepsilon^{I N V}$ is an $\mathrm{AR}(1)$ investment-specific technology shifter that increases the marginal efficiency of the conversion of investment into the capital stock. Equation 17 is the first order condition for the capital stock that decides the dynamics of Tobin's Q.

The wage is set as in Smets and Wouters (2003). The agent provides a differentiated labor service in the factor market and has monopoly power. If $\theta_{W} \in(0,1)$ is the Calvo parameter for nominal wage stickiness, $\sigma_{N} \geqslant 0$ is the reciprocal of the Frisch elasticity of labor and $\chi_{W}>1$ is the elasticity of substitution between labor varieties, nominal wage inflation is given by

$\hat{\pi}_{t}^{N W}-\iota_{W} \hat{\pi}_{t-1}^{C P I}=\beta \mathbf{E}_{t}\left(\hat{\pi}_{t+1}^{N W}-\iota_{W} \hat{\pi}_{t}^{C P I}\right)-\frac{\left(1-\beta \theta_{W}\right)\left(1-\theta_{W}\right)}{\theta_{W}\left(1+\sigma_{N} \chi_{W}\right)}\left[\hat{w}_{t}-\sigma_{N} \hat{N}_{t}-\sigma_{C} \frac{\hat{C}_{t}-\vartheta \hat{C}_{t-1}}{1-\vartheta}\right]+\varepsilon_{t}^{W M}$

The degree of indexation of wages to lagged CPI inflation is measured by $\iota_{W} \in[0,1] . \varepsilon^{W M}$ is a cost-push disturbance that can be interpreted as a shock to the mark-up of the real wage over the marginal rate of substitution between consumption and leisure (in square brackets) and as in Smets and Wouters (2007) follows an ARMA $(1,1)$ process defined as $\varepsilon_{t}^{W M}=\rho_{W M} \varepsilon_{t-1}^{W M}+\eta_{t}^{W M}-\nu_{W M} \eta_{t-1}^{W M}$ such that $\nu_{W M} \in[0,1)$.

\footnotetext{
${ }^{7}$ See Bergin (2006) and the references cited therein for alternative solutions to the unit-root problem in incomplete financial asset markets models.
} 
Market Clearing Final goods market-clearing requires that the production of the final good sector is absorbed by consumption, investment and government spending, each weighted by its respective steady-state share in output.

$$
\hat{Y}_{t}=\Xi_{C} \hat{C}_{t}+\Xi_{I} \hat{I}_{t}+\Xi_{G} \hat{G}_{t}
$$

The unmodelled fiscal sector is financed by lumpsum taxes and consumes a fixed proportion of output.

The intermediate tradable goods are sold both at home and exported.

$$
\hat{y}_{t}^{T}=\left(1-\xi_{M}\right) \hat{Y}_{H t}^{T}+\xi_{M} \hat{Y}_{H t}^{* T}
$$

The factor markets clear when the supply of labor and capital by the household is absorbed by demand from both the non-tradable and tradable sectors. $\varkappa_{N}$ and $\varkappa_{K}$ are the shares of labor and capital demand by the non-tradable sector in the aggregate demand for the respective factor of production.

$$
\begin{aligned}
& \hat{N}_{t}=\varkappa_{N} \hat{N}_{t}^{N T}+\left(1-\varkappa_{N}\right) \hat{N}_{t}^{T} \\
& \hat{K}_{t}=\varkappa_{K} \hat{K}_{t}^{N T}+\left(1-\varkappa_{K}\right) \hat{K}_{t}^{T}
\end{aligned}
$$

The inter-temporal flow of net foreign assets as a proportion of tradable output is given by

$$
\widehat{N F A}_{t}-\frac{1}{\beta} \widehat{N F A}_{t-1}=\xi_{M}\left(\widehat{N E x}_{t}+\hat{P}_{H t}^{* T}+\hat{Y}_{H t}^{* T}\right)-\xi_{M}\left(\hat{P}_{M t}^{T}+\hat{Y}_{M t}^{T}\right)
$$

Monetary Authority The monetary authority in the SOE follows a simple empirical Taylor-type rule to set the nominal interest rate, targetting CPI inflation and the level as well as changes in output.

$$
\hat{R}_{t}=\rho_{M O N} \hat{R}_{t-1}+\left(1-\rho_{M O N}\right)\left(\phi_{\pi} \hat{\pi}_{t}^{C P I}+\phi_{y} \hat{Y}_{t}\right)+\phi_{\Delta y}\left(\hat{Y}_{t}-\hat{Y}_{t-1}\right)+\eta_{t}^{M O N}
$$

Foreign Economy The model is closed by postulating that the foreign economy follows a simple closed-economy rational expectations model. Output, CPI inflation and the nominal interest rate are given by an Euler equation, Phillips curve and empirical 
monetary policy rule in the following sequence. ${ }^{8}$

$$
\begin{gathered}
\hat{Y}_{t}^{*}=\frac{1}{1+\vartheta^{*}} \mathbf{E}_{t} \hat{Y}_{t+1}^{*}+\frac{\vartheta^{*}}{1+\vartheta^{*}} \hat{Y}_{t-1}^{*}-\frac{1}{\sigma_{C}^{*}} \frac{\left(1-\vartheta^{*}\right)}{\left(1+\vartheta^{*}\right)}\left(\hat{R}_{t}^{*}-\mathbf{E}_{t} \hat{\pi}_{t+1}^{C P I *}\right)+\varepsilon_{t}^{Y *} \\
\hat{\pi}_{t}^{C P I *}=\frac{\iota^{*}}{1+\beta \iota^{*}} \hat{\pi}_{t-1}^{C P I *}+\frac{\beta}{1+\beta \iota^{*}} \mathbf{E}_{t} \hat{\pi}_{t+1}^{C P I *}+\frac{\left(1-\beta \theta^{*}\right)\left(1-\theta^{*}\right)}{\theta^{*}\left(1+\beta \iota^{*}\right)}\left(\hat{Y}_{t}^{*}+\sigma_{C}^{*} \frac{\hat{Y}_{t}^{*}-\vartheta \hat{Y}_{t-1}^{*}}{1-\vartheta^{*}}\right)+\varepsilon_{t}^{C P I *} \\
\hat{R}_{t}^{*}=\rho_{M O N}^{*} \hat{R}_{t-1}^{*}+\left(1-\rho_{M O N}^{*}\right)\left(\phi_{\pi}^{*} \hat{\pi}_{t}^{C P I *}+\phi_{y}^{*} \hat{Y}_{t}^{*}\right)+\phi_{\Delta y}^{*}\left(\hat{Y}_{t}^{*}-\hat{Y}_{t-1}^{*}\right)+\eta_{t}^{M O N *}
\end{gathered}
$$

$\sigma_{C}^{*}$ and $\vartheta^{*}$ are the foreign utility curvature and external habit coefficients while $\theta^{*}$ and $\iota^{*}$ are the Calvo parameter and indexation in price-setting respectively. Monetary policy is conducted in a way similar to that of the SOE. $\varepsilon^{Y *}$ and $\varepsilon^{C P I *}$ are foreign $\operatorname{AR}(1)$ output and CPI disturbances while $\eta^{M O N *}$ is an innovation to monetary policy.

\section{The Composition of the Real Exchange Rate}

The model-implied CPI-based real exchange rate is now written as the sum of its constituent relative prices. ${ }^{9}$ The first ingredient we define is $\operatorname{rer}^{T}$, the international relative price of tradables, that includes the nominal exchange rate. The second component, $\operatorname{rer}^{M}$ denotes the influence of the relative price of imports in terms of the domestic tradable good, i.e. the terms of trade, weighted by the share of tradables in total absorption as well as the share of imports in the tradable aggregate. Finally, $\operatorname{rer}^{N T}$ is the internal relative price of the non-tradable good in terms of the home-produced tradable good, weighted by the share of non-tradables in aggregate absorption.

$$
\widehat{R E x}_{t}^{C P I}=\underbrace{\left(\widehat{N E x_{t}}+\hat{P}_{t}^{C P I *}-\hat{P}_{H t}^{T}\right)}_{r e r_{t}^{T}} \underbrace{-\left(1-\xi_{N T}\right) \xi_{M}\left(\hat{P}_{M t}^{T}-\hat{P}_{H t}^{T}\right)}_{\operatorname{rer}_{t}^{M}} \underbrace{-\xi_{N T}\left(\hat{P}_{t}^{N T}-\hat{P}_{H t}^{T}\right)}_{r e r_{t}^{N T}}
$$

\footnotetext{
${ }^{8}$ We abstract from investment and fiscal policy in the foreign economy. In the foreign utility function, we assume a unitary Frisch elasticity of the labor supply while the production function is linear in hours. Justiniano and Preston $(2006,2010)$ use a similar New Keynesian model to model the US, and unlike in our case, they estimate the Frisch elasticity while also using wage rigidities and data. Alternatively, the foreign economy can be modelled as a vector autoregression as in Adolfson et al. (2007).

${ }^{9}$ This can easily be done by using the definition of the SOE aggregate price levels given in Equation 1 and Equation 2 in the primitive definition of the CPI-based real exchange rate, $\widehat{R E x}_{t}^{C P I}=\widehat{N E x}_{t}+$ $\hat{P}_{t}^{C P I *}-\hat{P}_{t}^{C P I}$.
} 
Importantly, since exports of the SOE only account for a negligible share of the Foreign economy, the export price has only an indirect effect on the real exchange rate through the export demand function given in Equation 11. Note that the above equation can also be written in terms of the inverse of the mark-up of the price-setting importer, i.e. the law of one price gap $\widehat{N E x}+\hat{P}^{C P I *}-\hat{P}_{M}^{T}$, if one subtracts and adds the import price to $\operatorname{rer}^{T} \cdot 10$

The above decomposition clarifies that a fall in the price of the home-produced tradable affects the real exchange rate through all three relative prices, the first leading to a real depreciation and the latter two triggering an appreciation. In the aggregate, the direction of the real exchange rate response depends on which relative price effect dominates. However, the impact of a fall in the relative price of non-tradables, originating from a fall in the absolute price of non-tradables, is ceteris paribus a real depreciation. Even though a rise in the relative price of non-tradables appreciates the currency in real terms, the mechanism is dissimilar to that used in the Balassa-Samuelson framework due to Balassa (1964) and Samuelson (1964). In a nutshell, the Balassa-Samuelson thesis focuses on a productivity increase in the tradable sector that leads to a decrease in prices and a concurrent rise in labor demand and the real wage. Since labor is perfectly mobile across the two sectors, costs and prices increase in the non-tradable sector, so that the relative price of non-tradables increases, leading to an overall appreciation of the real exchange rate. However, while the original analyses were set in a static frictionless environment, our model hinges on a CES hierarchy of prices and quantities exhibiting differing and, as we shall see in Section 4, sometimes extreme degrees of inertia. For example, prices in the non-tradable sector may even fall in response to a tradable sector-specific technology shock, in our set-up as the nominal marginal cost that is common to both sectors experiences a decline, generating a real depreciation of the currency.

\footnotetext{
${ }^{10}$ This alternative decomposition of the real exchange rate is given as $\widehat{R E x}_{t}^{C P I}=\left(\widehat{N E x}_{t}+\hat{P}_{t}^{C P I *}-\hat{P}_{M t}^{T}\right)+\left[1-\left(1-\xi_{N T}\right) \xi_{M}\right]\left(\hat{P}_{M t}^{T}-\hat{P}_{H t}^{T}\right)-\xi_{N T}\left(\hat{P}_{t}^{N T}-\hat{P}_{H t}^{T}\right)$
} 


\section{Estimation}

\subsection{Data}

The Canada-US case provides the ideal environment to take our SOE model to the data. Canada is a small and very open economy that conducts most of its international trade transactions with only one partner, the United States. Over the period 2003-2008, the US accounted for nearly 80 percent of Canada's exports and about 67 percent of its imports (Statistics Canada 2009). Naturally, and importantly for the purpose of this paper, the IMF's trade-weighted nominal effective exchange rate for the Canadian dollar is almost identical to the Canada-US exchange rate (see Figure 1).

We follow Dotsey and Duarte (2008) and Cristadaro et al. (2008) in mapping the production of domestic tradables in the theoretical model to goods and that of non-tradables to services. Accordingly, we use the goods and services components of the CPI to measure the price variables for the tradable and non-tradable sectors respectively. The influence of the deviations from the law of one price is captured through the use of the bilateral export and import price series between Canada and the US. In short, for Canada, we use real consumption, real investment, nominal wage inflation, CPI Goods inflation, CPI Services inflation and the nominal interest rate. For the US, we use real GDP, CPI inflation and the nominal interest rate. Bilateral series include export price inflation, import price inflation and the nominal Canada-US exchange rate. The data spans 1986 Q.I - 2009 Q.II. The series for interest rates, price inflations and wage inflation are demeaned. All other series enter the estimation in demeaned first-differences of their natural logarithms. These twelve time series are used to identify the twelve structural innovations in the theoretical model - $\eta^{T I}, \eta^{I N V}, \eta^{M O N}, \eta^{T}, \eta^{N T}, \eta^{W M}, \eta_{M}^{P M}, \eta_{H}^{* P M}, \eta^{Y *}, \eta^{C P I *}, \eta^{M O N *}$ and $\eta^{U I P}$. Table 1 relates the model analog to the observed data series we employ and also provides the unconditional moments of the data. Other particulars are detailed in the Appendix.

\subsection{Methodology}

We follow the Bayesian estimation methodology of Smets and Wouters (2007) and we refer the reader to the original paper for a detailed description. In a nutshell, the Bayesian paradigm facilitates the combination of prior knowledge about structural parameters with information in the data as embodied by the likelihood function. The blend of the prior 
and the likelihood function yields the posterior distribution for the structural parameters which is then used for inference. The appendix provides technical details on the estimation methodology.

\subsection{Priors}

An overview of our priors is presented in Table 2. The prior distributions given to the estimated structural parameters are quite diffuse and comparable to those used in other studies. The parameters that are not estimated are given dogmatic priors at calibrated values. The great ratios for investment and consumption are fixed, using the sample averages, at 0.176 and 0.577 . Of direct consequence to the composition of the real exchange rate in Equation 28, are the values we assign to two parameters governing the absorption of non-tradables and imports. The share of non-tradables in aggregate absorption $\xi_{N T}$ is fixed at 0.68 , the sample mean of the share of services in aggregate GDP. We obtain the share of imports in total absorption from Dib (2003) who uses a value of 0.28 , the mean import-to-GDP ratio during the period 1981-2002. Using these two ratios, the steady-state share of imports in the tradable aggregate $\xi_{M}$ is computed as 0.875. All other calibrated values are standard. These priors remain unaltered through all our estimations.

\subsection{Results from Baseline Specification}

\subsubsection{Posterior Distribution}

The medians and standard deviations of the posterior distributions are also reported in Table 2. The sector-specific technology shock processes exhibit low autocorrelation about 0.3 , possibly due to the fact that we do not use sector-specific output in our estimation. Almost all the Phillips curves require Calvo parameter values in the neighbourhood of 0.90 to fit the persistent inflation series. The only exception is the import price inflation series, the Phillips curve of which requires a lower Calvo parameter of 0.30 . However, the corresponding cost-push shock is more persistent than shocks to other Phillips curves with an $\operatorname{AR}(1)$ coefficient of 0.97 . In contrast, for all other inflation series, the shock $\operatorname{AR}(1)$ coefficients are quite low at slightly below 0.60 as in the case of wages and around the 0.30 mark for the remaining cases. Similarly, while the consumption habit coefficient is very high at about 0.93 , the autocorrelation of the time impatience shock is quite low at about 0.30. The estimate of the elasticity of substitution between non-tradable and tradable 
goods, at about 1.14, is higher than those found for the US by Rabanal and Tuesta (2007) and Cristadoro et al. (2008). The former find an extremely low value of 0.13 while the latter find higher values ranging between 0.50 and 0.80 . The trade elasticity is about 1.5 which is higher than the value of 0.80 obtained by Dib (2003) and lower than the mean of 1.80 obtained by Justiniano and Preston (2006) in similar exercises using Canadian data. We comment on the sizes of selected shock innovations in the following sub-sections. Other parameters are in the ballpark of those estimated for the US and the Euro-Area by Smets and Wouters $(2003,2007)$.

\subsubsection{The Dynamics of the Real Exchange Rate}

In Figure 2, we present the responses of the three components of the real exchange rate, the impacts of (a) the international relative price of tradables (b) the relative price of imports in terms of home-produced tradables and (c) the internal relative price of nontradables in terms of home-produced tradables, to various structural shocks. To prevent confusion, note that our definition of the influences from the relative prices, which are exhibited in Figure 2, subsumes both the weights and the signs so that the sum of the responses of the three components add up to the aggregate real exchange rate response. In Figure 3, we also present the dynamics trigered by the main shocks for a different decomposition of the real exchange rate defined in Footnote 10, viewed in terms of the law of one price gap. In our discussion, shocks are classified, admittedly imperfectly, into 'direct' shocks to the relative prices in Equation 28, other domestic shocks and external shocks (of US origin).

Direct Shocks to the Relative Prices: The deviation from uncovered interest parity appears as a wedge between the Canadian and the US nominal interest rates, raising the former while lowering the latter. Since this shock acts a risk-premium for Canadian borrowers, the currency depreciates very strongly in nominal terms. Imports become more expensive for the SOE, but due to nominal stickiness, the rise in import prices is less than one-to-one to the movement in the nominal exchange rate. The terms of trade deteriorates and has an appreciation effect on the real exchange rate. The rise in import prices raises CPI and since nominal marginal costs rise, it increases the price of domestic tradables and non-tradables. However, the movement in the relative price of non-tradables is a gentle fall, causing a mild though significant depreciation effect. In the aggregate, the real exchange rate deteriorates and mimics the behavior of the international relative price of 
tradables, with the nominal exchange rate playing the pivotal role.

On the other hand, the immediate impact of the tradable sector-specific technological disturbance is a fall in the price of tradable goods and a slow rise in aggregate quantities. This negative effect leads to a fall in aggregate CPI, decreasing the nominal costs of the non-tradable sector inducing a mild fall in prices in that sector. Hence, the relative price of non-tradables strongly increases and has an appreciation effect on the real exchange rate. Simultaneously the relative price of imports in terms of the domestic tradable also increases reinforcing the appeciation effect. However, the international relative price of tradables rises strongly. This positive movement negates the negative influences of the two other relative prices and overall, the movement is statistically insignificant.

A technology shock in the non-tradable sector induces a fall in prices which reflects in a fall in CPI in the aggregate. This fall in aggregate CPI is stronger than in the case of the tradable sector technology shock, as non-tradables are the dominant component of the SOE GDP. The fall in nominal costs also leads to a mild decrease in the price of tradable goods, but in the net, the relative price of non-tradables in terms of tradables decreases and exerts a depreciation effect on the real exchange rate. The effect of this shock is statistically insignificant on the other relative prices. Overall, the real exchange rate follows the dynamic path of the (depreciation effect from the) relative price of nontradables and moves in almost in the same quantum at most horizons.

The size of the innovation of the import price innovation is quite high at almost 4.5 percent, reflecting the high volatility of the data series. The shock generates a strong rise in import prices and hence acts as an exogenous deviaton from the law of one price (See also Figure 3 for the persistent fall in the law of one price gap). The subsequent sharp push to CPI generates a slow and persistent rise in prices of non-tradables, tradables and exports, through the nominal cost channel. Observe that the quantitative impact on the relative price of imports is stronger than that of the response of the relative price of non-tradables to the non-tradable sector-specific shock. The response of the international relative price of tradables is insignificant while the relative price of non-tradables falls gently. The appreciation effect from the relative price of imports swamps the much weaker depreciation effect from the relative price of non-tradables and the currency strongly appreciates and replicates the effect emanating from the relative price of imports.

In contrast, despite the high magnitude of the export price innovation, at about 2.5 percent, the exchange rate response is mild as the shock only has an indirect impact 
through the foreign export demand function. The rise in prices lowers foreign demand for the SOE exports. The SOE experiences a fall in consumption, investment and production and the lack of demand causes prices in both the tradable and non-tradable sectors to fall. The relative price of non-tradables however rises gently. The monetary authority lowers the interest rate to counter the fall in economic activity and the currency experiences a nominal depreciation, though the movement is statistically significant only for a couple of quarters. Import prices rise modestly but the response becomes insignificant quite quickly and the terms of trade worsens more due to the fall in the price of domestic tradables. The overwhelming influence on the exchange rate is from the international relative price of tradables which rises. The currency depreciation is statistically insignificant after about 4 quarters.

Other Domestic Shocks: The cost-push shock to the real wage raises the prices of non-tradables and tradables slowly while the relative price of non-tradables falls. The impact on import prices is insignificant, but the rise in the prices of home tradables ensures that the terms of trade improves. The international relative price of tradables falls slowly due to the nominal appreciation triggered by the rise in the interest rate in reaction to the price hike. Cumulatively, the response of the real exchange rate is insignificant.

The investment-specific technology shock increases the conversion of the final good into the capital stock and the slow fall in marginal costs reflects in the decrease in prices in both sectors. Since prices in the non-tradable sector are slightly stickier than in the tradables sector, the latter falls more causing a rise in the relative price of non-tradables and generates a very mild appreciation effect on the currency. The monetary authority reacts to the rise in output and raises the nominal interest rate, immediately appreciating the currency in nominal terms, decreasing the international relative price of tradables. The appreciated currency leads to a decline in import prices and improves the SOE terms of trade. In the aggregate, the very mild appreciation effect emanating from the relative price of non-tradables and the much stronger appreciation effect from the international relative price of tradables goods dominates the (initially) positive terms of trade effect causing a real appreciation of the currency on impact. The real exchange rate follows the international relative price of tradables closely as the sign of the response reverses after about three years.

The monetary policy shock raises the SOE nominal interest rate which induces a fall in domestic demand, decreases prices in the tradable and non-tradable sectors and 
appreciates the currency in nominal terms. The appreciated currency leads to a fall in the price of imports and in combination with the (stronger) fall in the price of the home-produced tradable good, significantly improves the terms of trade. The dominant effect is exerted by the international relative price of tradables and the currency strongly appreciates in real terms, almost on a one-to-one basis.

The consumption shock is modelled as an exogenous increase in the economy's time impatience to consume, raising prices in both intermediate sectors slowly. The predominant influence in this case is from the international relative price of tradables that appreciates very strongly due to the currency's nominal appreciation that follows the hike in the interest rate and the aggregate real exchange rate responds almost identically in both direction and quantum.

Foreign Economy Shocks: The foreign demand shock affects the foreign Euler equation and raises aggregate demand, and importantly for the SOE, the demand for exports rises which stimulates production in the SOE. Nominal interest rates rise in both economies, in the SOE in a lesser quantum than in the bigger economy and the SOE currency depreciates in nominal terms. Foreign CPI also rises due to the demand shock and adds to the cost of procurement of the foreign good for the SOE importer. This raises import prices and deteriorates the SOE terms of trade. Prices fall persistently in both intermediate sectors as domestic resources are spent to feed the foreign output boom. The relative price of non-tradables falls gently but significantly for about four years, depreciating the currency. This is complemented by the much stronger dynamics of the international relative price of tradables, as the currency experiences a strong real depreciation.

On the other hand, the shock to the foreign Phillips curve raises the procurement price of foreign tradables, deteriorating the SOE terms of trade. The impact on the relative price of non-tradables is insignificant. The real exchange rate inherits the dynamic behavior of the international relative price of tradables over the forecast horizon. The foreign interest rate shock evokes responses that are qualitatively symmetric to those generated by the SOE interest shock and the SOE currency depreciates. The bottomline is that in response to all the US shocks, the real exchange rate follows the time path of the international relative price of tradables. 


\subsubsection{Variance Decomposition}

We now dissect the variance of the forecast errors of the real exchange rate and its component prices to evaluate the relative contributions of the twelve shocks embedded in the model, in the first four columns of Table 3. Additionally, in the last column, we also report the decomposition for the deviation from the law of one price which is simply the difference between the international relative price of tradables and the relative price of imports in terms of the home-produced tradable.

The random deviation from interest parity is the main driver of the Canada-US real exchange rate, accounting for above 60 percent on impact, declining to about 40 percent over the horizon of 10 years. Justiniano and Preston (2006) obtain comparable results for Canada while Cristadoro et al. (2008) and Rabanal and Tuesta (2010) report the dominance of this shock in the decomposition of the Euro-Dollar exchange rate. The combined influence of sector-specific technology shocks pales in comparison to that of the UIP shock, at less than 5 percent at any horizon. Between the two technology shocks, the non-tradable sector disturbance, through its strong depreciation effect on the currency, is relatively more potent. As we noted in the impulse response analysis, the tradable sector shock generates opposing effects from the constituent relative prices and the overall movement observed in the real exchange rate is statistically insignificant. The cost-push shock to import prices is much more important than the internal sector-specific shocks, with its influence increasing over the horizon from about 7 percent on impact to about 18 percent at a 10 year horizon. In contrast, the export price shock despite being of high volatility, is less important contributing less than 5 per cent at any horizon. This result is an artifact of our SOE assumption that allows for only an indirect impact of export prices on the exchange rate through the export demand function and the relevant dynamics in foreign absorption. ${ }^{11}$

The Canadian nominal interest rate innovation is important, contributing about 15 percent on impact, with its influence mildly decreasing over time. Shocks to the real wage as well as the components of aggregate demand - investment and consumption - have very little influence, together accounting for less than 10 percent at all forecast-horizons. Similar to Justiniano and Preston $(2006,2010)$, we also find that shocks of US origin

\footnotetext{
${ }^{11}$ It may be a reasonable conjecture that the export price shock would matter more in a two-country set-up when the export price and corresponding data series enter the definition of the real exchange rate directly.
} 
contribute negligibly to the forecast volatility.

What shocks drive the component relative prices? Not surprisingly, the variance decomposition of the international relative price of tradables, the predominant player in the impulse responses, is very similar to that of the real exchange rate, except for the milder impact of the import price mark-up shock. The UIP shock exerts a very potent influence on the international relative price of tradables, almost replicating the pattern observed for the real exchange rate over time. The UIP shock is less important for the relative price of imports, accounting for below 40 percent on impact and 20 percent in the long run, due to the strong influence of the import price mark-up shock whose influence increases over time from under 40 percent to about 55 percent at the 10 year mark. Interestingly, the relative price of non-tradables, is dominated by tradable sector technology shocks rather than those in the non-tradable sector. While nominal stickiness, shock size and persistence are only slightly different between the two sectors, since tradables constitute a smaller proportion of GDP, the tradable sector shock has a milder negative effect on the the aggregate price level and hence the nominal marginal costs common to both sectors, thereby generating only a slight decline in the absolute price of non-tradables. Consequently, the relative price moves strongly. On the other hand, the non-tradable sector shock induces a persistent decline in nominal marginal costs and hence also in the price of tradables. Thus the variability generated in the relative price of non-tradables is more gentle than in the former case. Finally, the law of one price gap (not explicitly defined in the disaggregation given in Equation 28), which is essentially the difference between the first two relative prices that we examined, is almost exclusively driven by two shocks: the import price mark-up shock and the UIP shock. However, the impact of the UIP shock is short-lived and in the long run, the import mark-up shock drives the deviation from the law of one price.

A highlight of the variance decomposition is the modest influence of tradable or nontradable sector-specific disturbances in determining real exchange rate dynamics. Dotsey and Duarte (2008) and Corsetti, Dedola and Leduc (2008) have demonstrated that theoretical DSGE models using non-tradables in combination with other frictions such as nominal stickiness can replicate the real exchange rate persistence and volatility observed in the data, conditional on specific structural shocks and parametric configurations. While our methodology relies considerably on the exogenous shocks to match the data, the impulse responses presented in Subsection 4.4.2 indicate that an impetus from a disturbance 
specific to the non-tradable sector can indeed help the relative price of non-tradables guide the behavior of the exchange rate, quite in the spirit of Dotsey and Duarte (2008). However, in a broader context, when we allow the exchange rate to be driven by a wider array of stochastic disturbances, the tradable component, i.e. the international relative price of tradables and the relative price of imports and associated shocks generate even stronger real exchange rate dynamics. Naturally, the influence of the non-tradable sector shock diminishes to negligible proportions in the variance decomposition. In fact, import price shocks appear to be more potent in driving the exchange rate, even though the relative price of imports is assigned a much lower weight in the composition of the real exchange rate. $^{12}$

\section{Alternative Specifications}

We now assess how the contributions of the relative prices and associated disturbances change when we subject the baseline model to perturbations, adding or removing elements one at a time. The estimation results are reported in Table 3 together with those obtained in the baseline case. The impulse response functions of the relative prices of non-tradables and imports and the real exchange rate and the variance decompositions of the real exchange rate at a 1 year horizon are presented in Table 4 and Table 5 respectively. In each estimation, we maintain equality between the number of shocks and observables that we use.

The Real Exchange Rate as Observable Instead of using nominal exchange rate depreciation as the observable series in the estimation, we use the demeaned level of the CPI-based real exchange rate computed from the data, as in Rabanal and Tuesta (2007) and Cristadoro et al. (2008). Most parameter estimates barely differ. However, the size of the import price innovation decreases considerably from 4.34 in the baseline case to about 3.50 while the UIP innovation increases from 0.28 to $0.40 .{ }^{13}$ The new parameter estimates hardly matter for the qualitative contributions of the relative prices in the aggregate

\footnotetext{
${ }^{12}$ Given our calibration, the weights assigned to the relative prices of imports and non-tradables in the composition of the exchange rate are $\left(1-\xi_{N T}\right) \xi_{M}=0.28$ and $\xi_{N T}=0.68$ respectively.

${ }^{13}$ Demeaning a depreciation rate, i.e. a growth rate, is equivalent to assuming a linear trend in the level of the nominal exchange rate. The detrended exchange rate is less volatile than the demeaned level of the real exchange rate, explaining the rise in the innovation size.
} 
real exchange response. As can be seen in Table 4, the direction of the real exchange rate response is predominantly determined by the relative price of non-tradables only in the case of the non-tradable sector technology shock. But due to the increased size of the UIP innovation, it makes a higher contribution of about 65 percent in the variance decomposition.

Fixing Nominal Stickiness Since our estimates of price and wage stickiness are at the higher end of the range reported in the literature, we check if fixing these parameters at more reasonable values will impact our main results. Somewhat arbitrarily, we set all Calvo parameters for the price and wage Phillips curves at 0.75 implying a price change every 4 quarters while fixing all indexation parameters at 0.25 . Notably, the persistence coefficients of all shocks affecting the Phillips curves are now higher than in the baseline case. However, the flavor of the main results does not change as the international relative price of tradables dominates the dynamics of the exchange rate in most impulse responses. The UIP shock still contributes about 45 percent of the forecast variance.

PPI We now experiment with an alternative measure of home-produced tradable good prices. Instead of using CPI Goods as in Cristadoro et al. (2008), we follow Rabanal and Tuesta (2007) in employing the producer price index, as it may be relatively less contaminated by non-tradable elements as the prices of distribution services. The persistence parameter of the tradable sector technology shock increases noticeably from 0.21 in the baseline case to 0.35 , while other parameter values remain similar. This however has little impact on the variance decomposition as the UIP shock continues to dominate.

Producer Currency Pricing The procurement cost of the tradable good from the foreign or home producer is transmitted immediately to import and export prices facing the aggregation sector. In other words, the law of one price gap induced by the pricesetting importer in the baseline model disappears. Consequently, we remove the import and export price series and the corresponding cost-push shocks from the estimation. As in previous specifications, the relative price of non-tradables matters for the aggregate movement in the real exchange rate only in the case of the non-tradable sector-specific shock. The variance decomposition is still favor of the UIP shock. 
No UIP Shock and Nominal Exchange Rate Data As an extreme experiment, we now impose pure uncovered interest parity and simultaneously remove the nominal exchange rate series from the estimation. ${ }^{14}$ The most noticeable change is in the estimate of the Calvo parameter in the import Phillips curve which increases dramatically from the 0.30 to about 0.80 . At the same time, the persistence of the corresponding shock decreases from 0.97 to about 0.30 . The innovation of the import price shock also shows a substantive decline in size from about 4.30 percent in the baseline case to about 1.80 percent, indicating that the presence of the volatile nominal exchange rate series in the marginal costs of the importing firm, adds considerably to the innovation size. Qualitatively, the real exchange rate follows the relative price of non-tradables in response to both sector-specific shocks, although the dynamic induced by the tradable sector shock is quantitatively much weaker. Note however, that domestic sector-specific disturbances still exert a negligible influence, in unison accounting for less than 5 percent. Despite the lower estimated volatility of the import price shock, it contributes about 14 percent of the variance and the export price shock's contribution rises to 13 percent. Importantly, quite distinct to the baseline case, the US demand shocks via SOE export sales exert a considerable influence on the exchange rate. It contributes about 23 percent as does the Canadian monetary policy innovation.

Other Checks ${ }^{15}$ The main results favoring the importance of the purely tradable component of the real exchange rate hold when (a) we remove the sector-specific technology shocks and instead use price-mark up shocks in each intermediate sector (b) $\mu_{N T}$ the elasticity of substitution between non-tradables and tradables is set to 0.001 implying near Leontief complementarity between the two and (c) physical capital accumulation is removed from the model.

\footnotetext{
${ }^{14}$ This experiment is necessary because the extremely potent influence of the UIP shock may mask the importance of other shocks in the model. Observe that a variance decomposition is a 'relative' exercise. Even if a shock generates a strong impulse response, its contribution to aggregate volatility will be dominated by other shocks that generate even stronger impulses. Since the nominal exchange rate is now withdrawn from the empirical exercise, our focus is on the relative price of imports and the relative price of non-tradables. The percentage contributions of shocks have to be interpreted in a model-specific context.

${ }^{15}$ These results are not exhibited and are available on request.
} 


\section{Conclusion}

In the light of inconclusive evidence offered by the reduced-form literature on the importance of the relative price of non-tradable goods compared to that of internationally traded goods on the real exchange rate, this paper provided a alternative, structural treatment of the same issue. In particular, we aimed to understand which prices, and conditional on which structural shocks, matter the most for real exchange rate dynamics. To this end, we estimated a small open economy DSGE model on Canada-US macroeconomic time series over 1986-2009.

Consistent with the theoretical literature, e.g. Dotsey and Duarte (2008), the results indicate that a strong impetus from a disturbance specific to the non-tradable sector can indeed help the relative price of non-tradables in terms of home-produced tradables guide the behavior of the exchange rate. However, our subsequent findings somewhat challenge the importance of the relative price of non-tradables in a broader context: the purely tradable component, i.e. the international relative price of tradables as well as the relative price of imports, clearly generates even stronger aggregate real exchange rate dynamics for all other shocks irrespective of the structural origin of the disturbance. The two prime players in the forecast variance decomposition of the real exchange rate are the UIP shock and the import price mark-up shock, both of which generate deviations from the law of one price. The former exerts its influence mostly via the international relative price of tradables while the latter generates changes predominantly in the relative price of imports. The influence of internal sector-specific disturbances on real exchange rate variability pales in comparison. Our findings complement the statistical results favoring the importance of its purely tradable component for the real exchange rate reported by Engel (1999), Chari, Kehoe and McGrattan (2002) and Wolden Bache et al. (2009).

This study may be extended in many directions. A first step would be to examine the behavior of other bilateral exchange rates in the OECD within the theoretical framework we constructed. However, as mentioned earlier in the text, there is no unique way of positioning non-tradables in a DSGE model and results may be sensitive to the set-up. Bems (2008) documents that investment also has a substantial non-traded component, a feature we cannot control for given our simple aggregation choice. Hence, differentiating between consumption and investment deflator-based real exchange rates may be another useful avenue to explore in future research. 


\section{A Appendix}

\section{A.1 Data series}

For Canada, we use the Statistics Canada database for GDP at market prices, personal consumption expenditures, business gross fixed capital formation, overnight call money financing rate, CPI, CPI Goods, CPI Services and the bilateral export and import prices as well as the nominal exchange rate with the US. The Canada-US import-export prices are Paasche current-weighted indices broadly based on prices of commodities that include agricultural products and livestock, crude materials as oil along with finished products as machinery and automobiles. The import-export prices reported in CanSim Tables 228.0020 (1986Q1-1997Q4 Discontinued), 228.0039 (1997Q1-2007Q4 Discontinued) and 228.0051 (2002Q1-till date) are concatenated using the conversion factors for dates that overlap between these series. This limits our sample period to 1986Q1-2009Q2. The series on the producer price index and nominal wages are gleaned from the International Financial Statistics database of the International Monetary Fund. We obtain nominal GDP, CPI and the federal funds rate for the US from the FRED II database. All raw series, except the interest rates, are seasonally adjusted by the Census X12 method. The demeaned nominal interest rates are divided by 4 to translate them into quarterly terms. We express all other series as indices based on 2002Q2 and then multiply their natural logarithms by 100. These series are fed into the model in demeaned first differences while the nominal interest rates enter the estimation in levels. For the first variant of the model, the real exchange rate is computed from the nominal exchange rate and the aggregate CPIs from the two countries and then logged and demeaned. This variable enters the estimation in levels.

\section{A.2 Estimation}

We use 525000 iterations of the Random Walk Metropolis Hastings algorithm to simulate the posterior distributions and achieve acceptance rates of about 40 percent in all our specifications. We monitor the convergence of the marginal posterior distributions using CUMSUM statistics as defined by Bauwens et al. (1999). We discard the initial 25000 draws to compute the posterior moments in each case. The distributions of impulse response functions and variance decompositions that we present are computed from 150 
random draws from the posterior. This strategy ensures that our results are not contingent on a particular vector of parameter values such as the posterior median or the mode.

\section{References}

[1] Adolfson, Malin, Stefan Laseen, Jesper Linde and Mattias Villani, 2007. "Bayesian Estimation of an Open Economy DSGE model with Incomplete Pass-through," Journal of International Economics 72, pp.481-511.

[2] Backus, David, Patrick Kehoe and Finn Kydland, 1994. "Dynamics of the Trade Balance and the Terms of Trade: The J-Curve?". American Economic Review 84, pp.84-103.

[3] Balassa, Bela, 1964. "The Purchasing-Power Parity Doctrine: A Reappraisal". Journal of Political Economy 72, pp.584-596.

[4] Bauwens, Luc, Michel Lubrano and Jean-Francois Richard, 1999. "Bayesian Inference in Dynamic Econometric Models". Oxford University Press.

[5] Bems, Rudolfs, 2008. "Aggregate Investment Expenditures on Tradable and Nontradable Goods". Review of Economic Dynamics 11, pp.852-883.

[6] Benigno, Gianluca and Christoph Thoenissen, 2008. "Consumption and Real Exchange Rates with Incomplete Markets and Non-traded Goods". Journal of International Money and Finance 27, pp.926-948.

[7] Bergin, Paul, 2006. "How Well Can the New Open Economy Macroeconomics Explain the Exchange Rate and Current Account?". Journal of International Money and Finance 25, pp.675-701.

[8] Betts, Caroline and Michael Devereux, 2000. "Exchange Rate Dynamics in a Model of Pricing to Market". Journal of International Economics 50, pp.215-244.

[9] Betts, Caroline and Timothy Kehoe, 2008. "Real Exchange Rate Movements and the Relative Price of Non-traded Goods". Federal Reserve Bank of Minneapolis Research Department Staff Report 415. 
[10] Burstein, Ariel, Martin Eichenbaum and Sergio Rebelo, 2006. "The Importance of Nontradable Goods' Prices in Cyclical Real Exchange Rate Fluctuations". Japan and the World Economy 18, pp.247-253.

[11] Chari, Varadarajan, Patrick Kehoe and Ellen McGrattan, 2002. "Can Sticky Price Models Generate Volatile and Persistent Real Exchange Rates?". Review of Economic Studies 69, pp.533-563.

[12] Corsetti, Giancarlo, Luca Dedola and Sylvain Leduc, 2008. "High Exchange-rate Volatility and Low Pass-through". Journal of Monetary Economics 55, pp.1113-1128.

[13] Cristadoro, Riccardo, Andrea Gerali, Stefano Neri and Massimiliano Pisani, 2008. "Real Exchange Rate Volatility and Disconnect: An Empirical Investigation". Temi di discussione 660, Bank of Italy, Economic Research Department.

[14] Devereux, Michael and Charles Engel, 2002. "Exchange Rate Volatility, Exchange Rate Pass-through, and Exchange Rate Disconnect". Journal of Monetary Economics 49, pp.913-940.

[15] Dib, Ali, 2003. "Monetary Policy in Estimated Models of Small Open and Closed Economies". Bank of Canada Working Papers 03-27.

[16] Dotsey, Michael and Margarida Duarte, 2008. "Nontraded Goods, Market Segmentation and Exchange Rates". Journal of Monetary Economics 55, pp.1129-1142.

[17] Engel, Charles, 1999. "Accounting for U.S. Real Exchange Rate Changes". Journal of Political Economy 107, pp.507-538.

[18] Farrant, Katie and Gert Peersman, 2006. "Is the Exchange Rate a Shock Absorber or Source of Shocks? New Empirical Evidence". Journal of Money, Credit and Banking 38 , pp.939-962.

[19] Jacob, Punnoose and Gert Peersman, 2008. "Dissecting the Dynamics of the US Trade Balance in an Estimated Equilibrium Model". Faculty of Economics and Business Administration, Ghent University Working Paper No. 08/544.

[20] Justiniano, Alejandro and Bruce Preston, 2010. "Can Structural Small Open Economy Models Account for the Influence of Foreign Disturbances?". Journal of International Economics. In Press. 
[21] Justiniano, Alejandro and Bruce Preston, 2006. "Can Structural Small Open Economy Models Account for the Influence of Foreign Disturbances?". CAMA Working Papers 2006-12, Australian National University, Centre for Applied Macroeconomic Analysis

[22] Lubik, Thomas and Frank Schorfheide, 2006. "A Bayesian Look at the New Open Economy Macroeconomics". NBER Macroeconomics Annual 20, pp.313-366.

[23] Rabanal, Pau and Vincente Tuesta, 2010. "Euro-Dollar Real Exchange Rate Dynamics in an Estimated Two-Country Model: An Assessment". Journal of Economic Dynamics and Control 34, pp.780-797.

[24] Rabanal, Pau and Vincente Tuesta, 2007. "Nontradable Goods and the Real Exchange Rate". La Caixa Working Paper 03/2007.

[25] Samuelson, Paul, 1964. "Theoretical Notes on Trade Problems". Review of Economics and Statistics 46, pp.145-154.

[26] Smets, Frank and Rafael Wouters, 2007. "Shocks and Frictions in US Business Cycles: A Bayesian DSGE Approach". American Economic Review 97, pp.586-606.

[27] Smets, Frank and Rafael Wouters, 2003. "An Estimated Dynamic Stochastic General Equilibrium Model of the Euro Area". Journal of the European Economic Association 1, pp.1123-1175.

[28] Statistics Canada, 2009. http://www40.statcan.gc.ca/101/cst01/gblec02a-eng.htm

[29] Wolden Bache, Ida, Kjersti Næss, and Tommy Sveen, 2009. "Revisiting the Importance of Non-tradable Goods' Prices in Cyclical Real Exchange Rate Fluctuations". Norges Bank Working Paper 2009/3. 


\section{FIGURES}

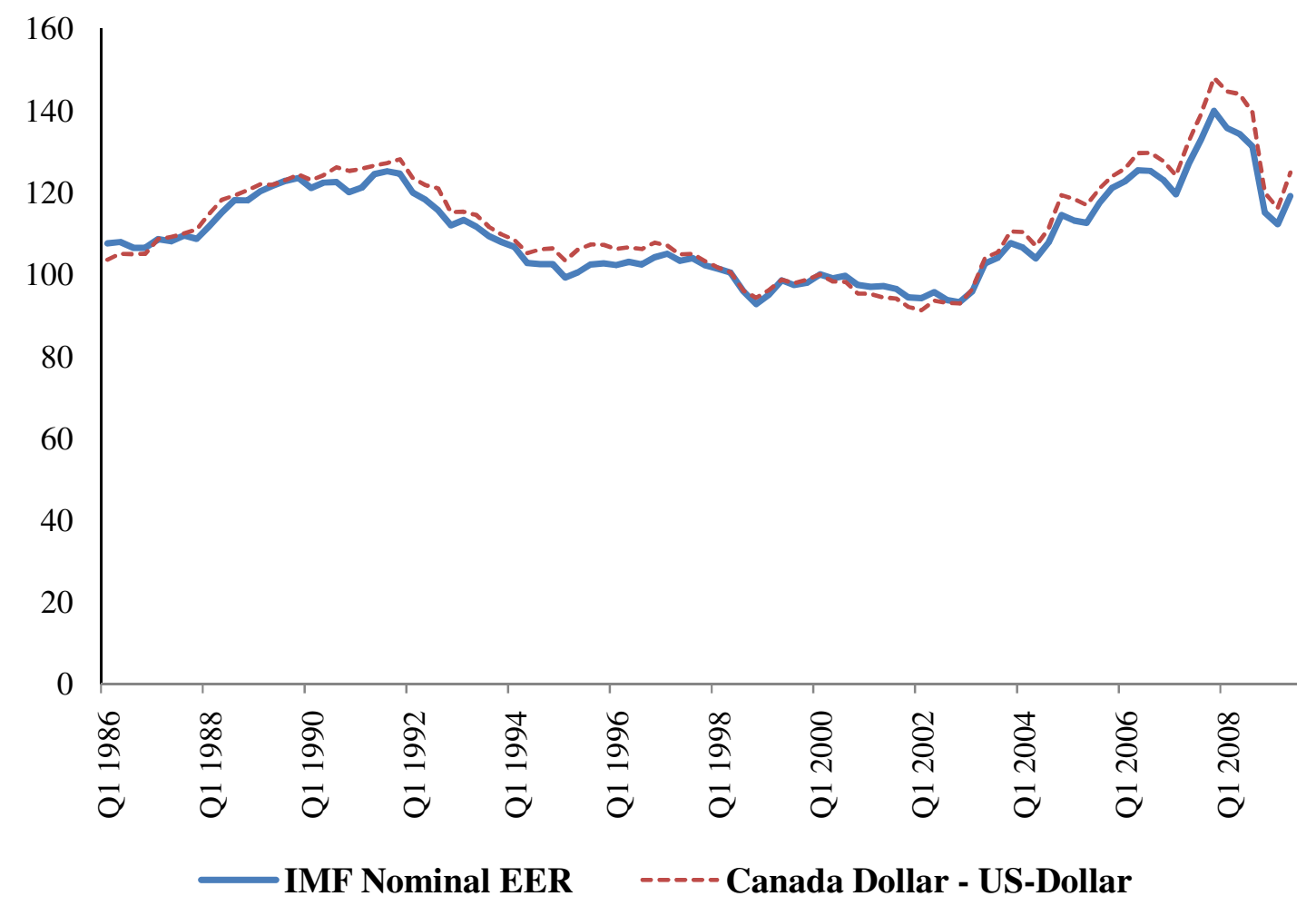

Figure 1: The Canada-US Nominal Exchange Rate (1986-2009) 


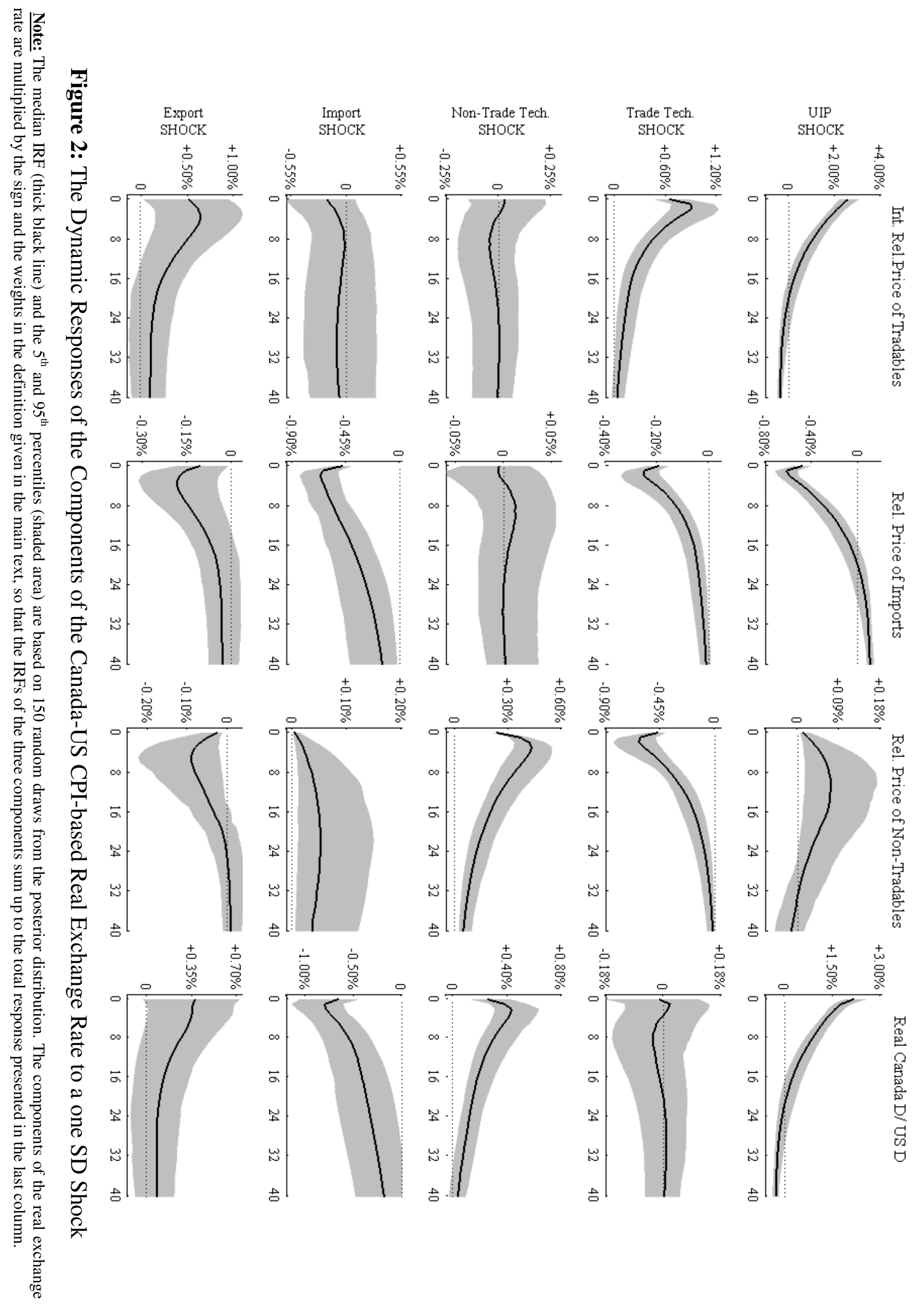




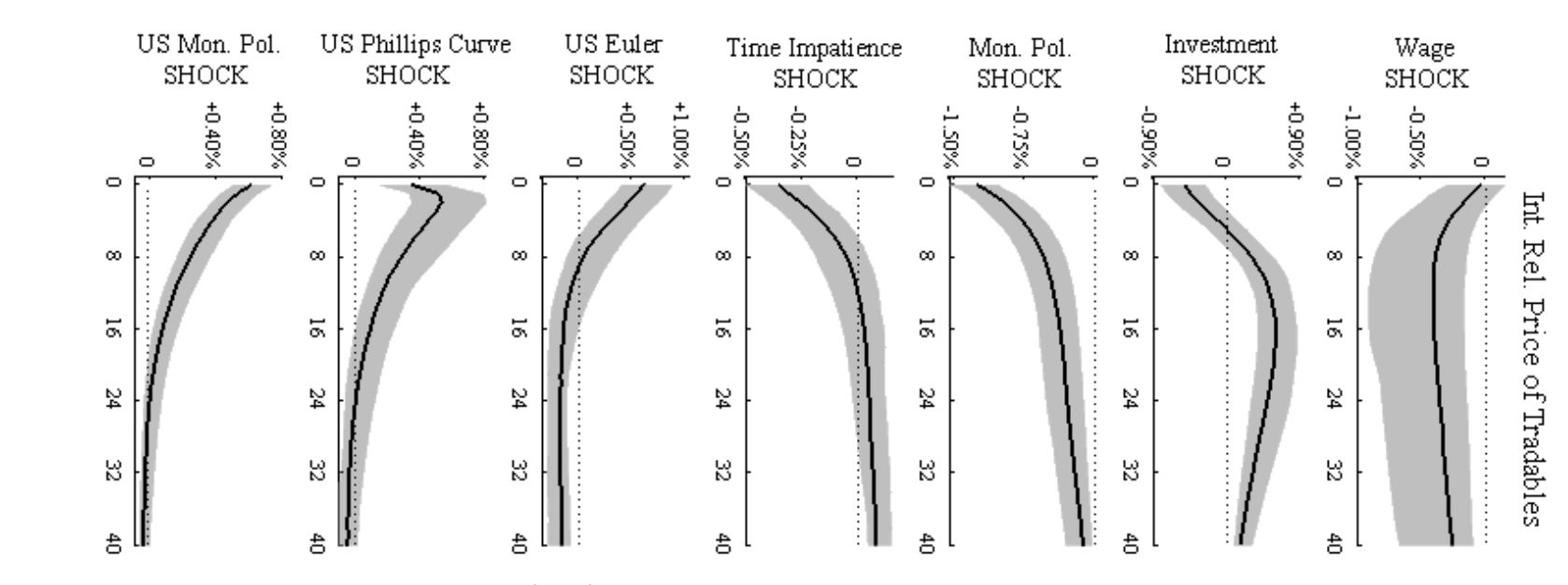

品.

\section{है}

항

幽.

孚

है

题:

응
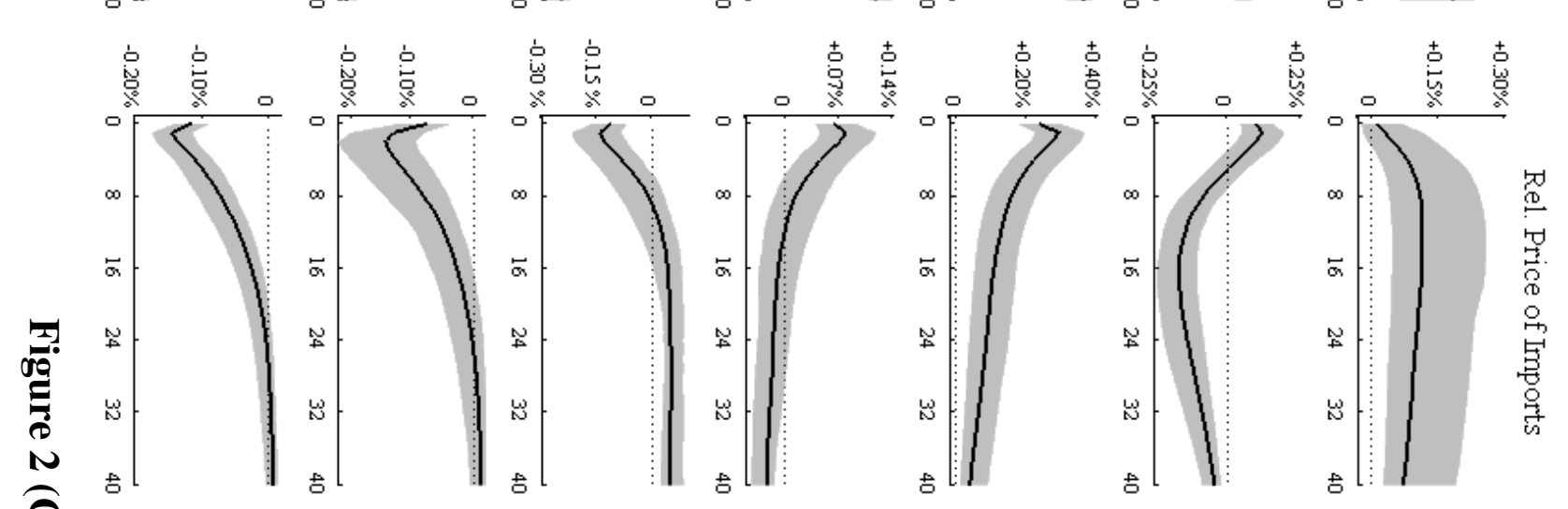

๙

․ㅛ용

हे

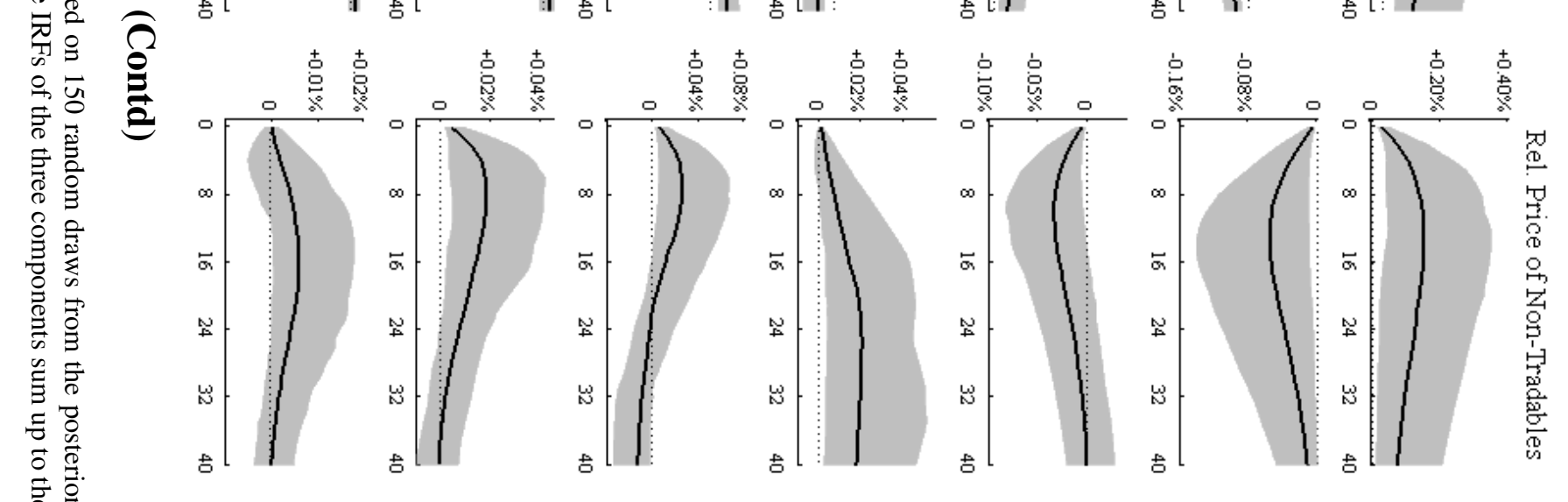

훙.

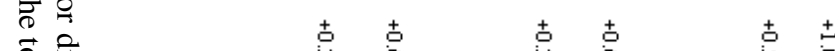

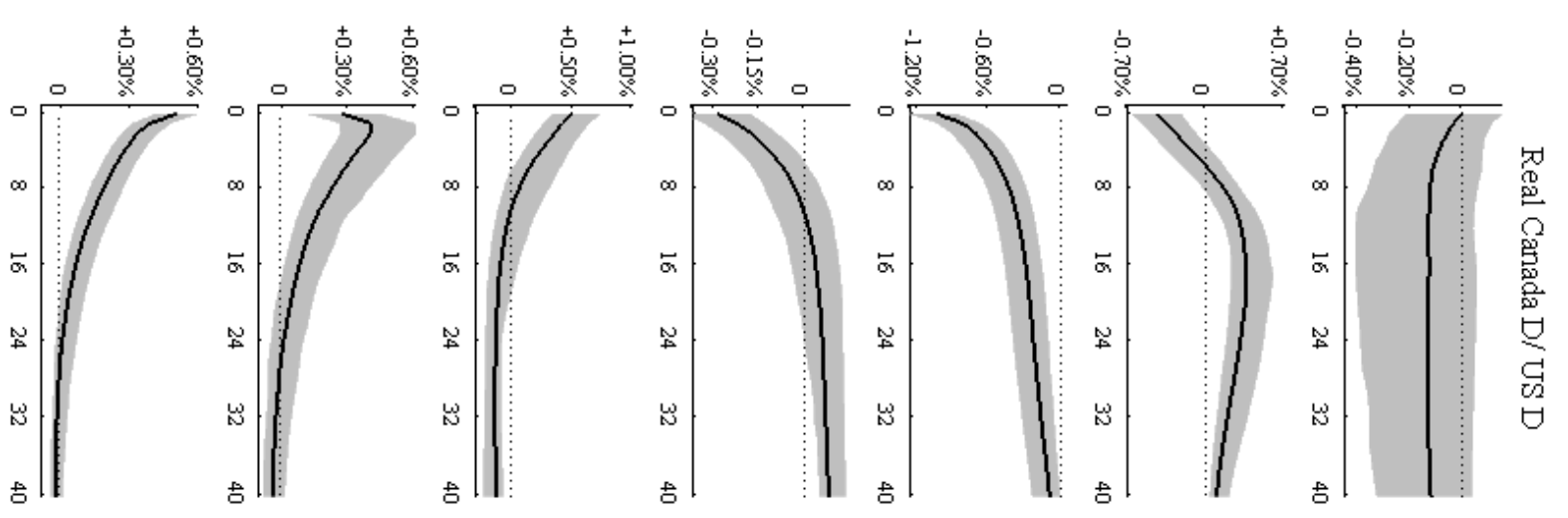

焉 
№응

흘 흉

ब.

돌

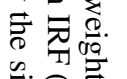

몰. 를

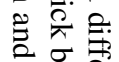

है

…

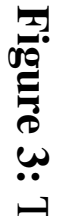
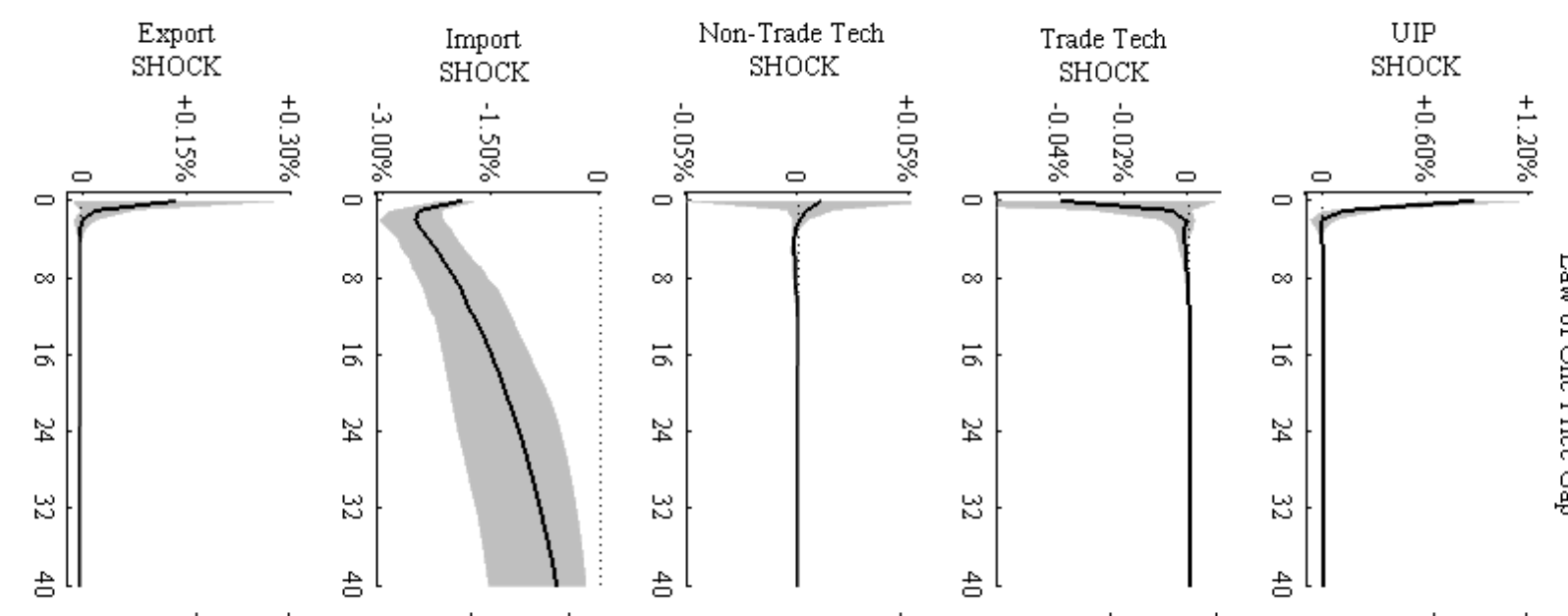

可.

훙 항

के

:

당

ㅁ.

융

ㅋ. 릉

产. 釆

के के

年

를

F漹

牙吕

옹

F

居 产 롱.

요용

政

률를

战

政

응

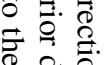

응.
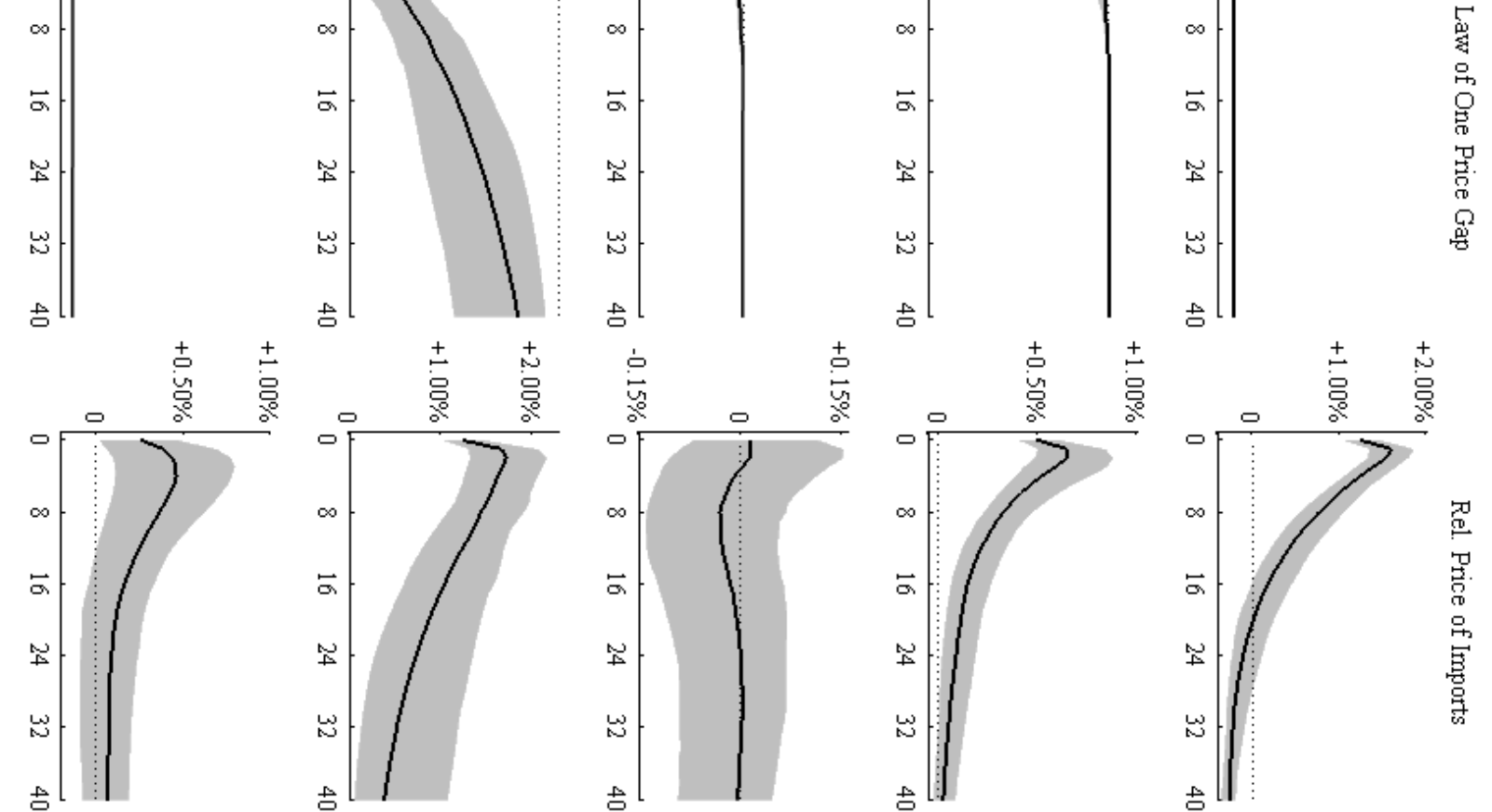

远

记

政

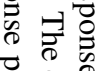

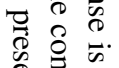
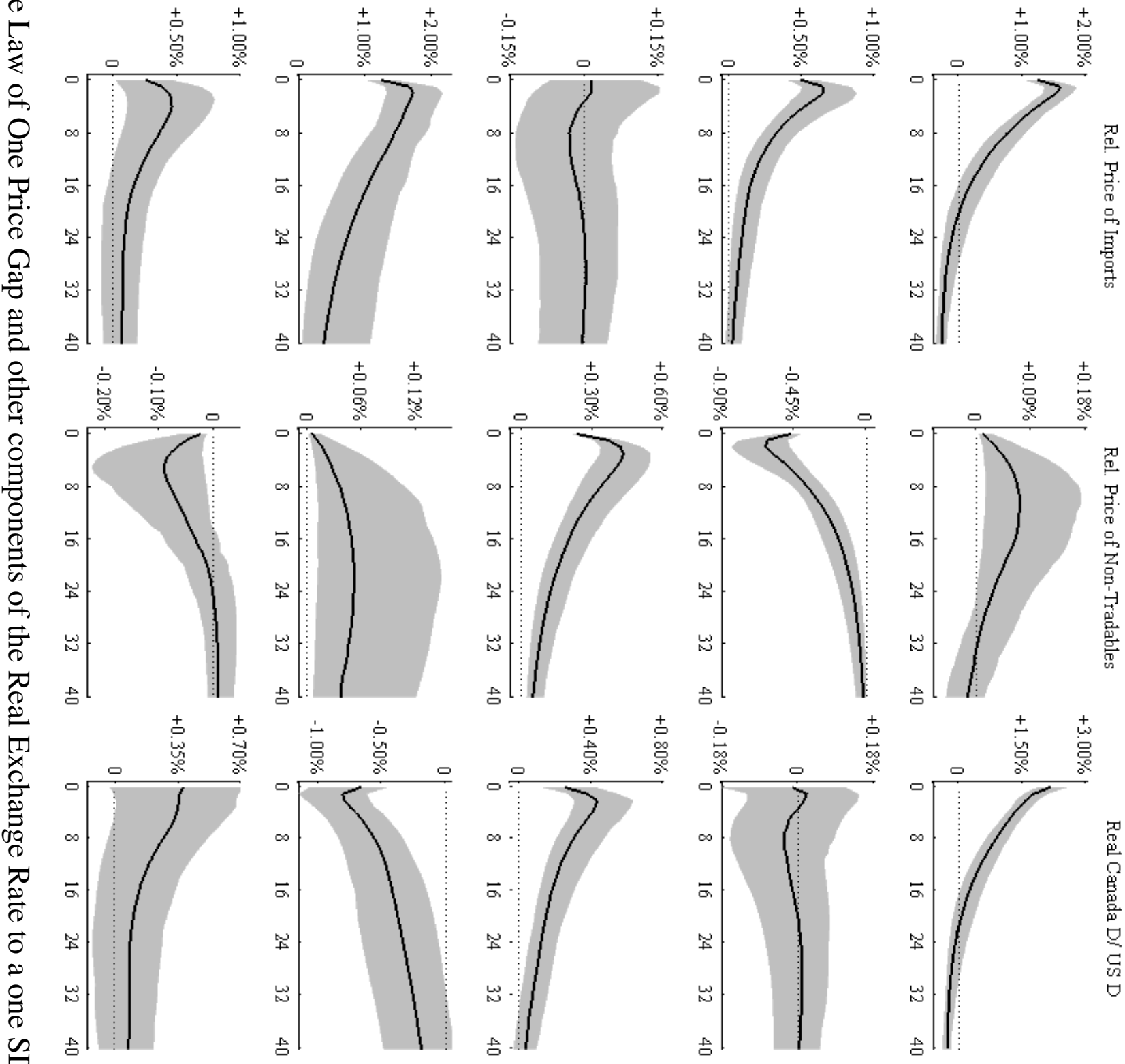

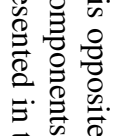
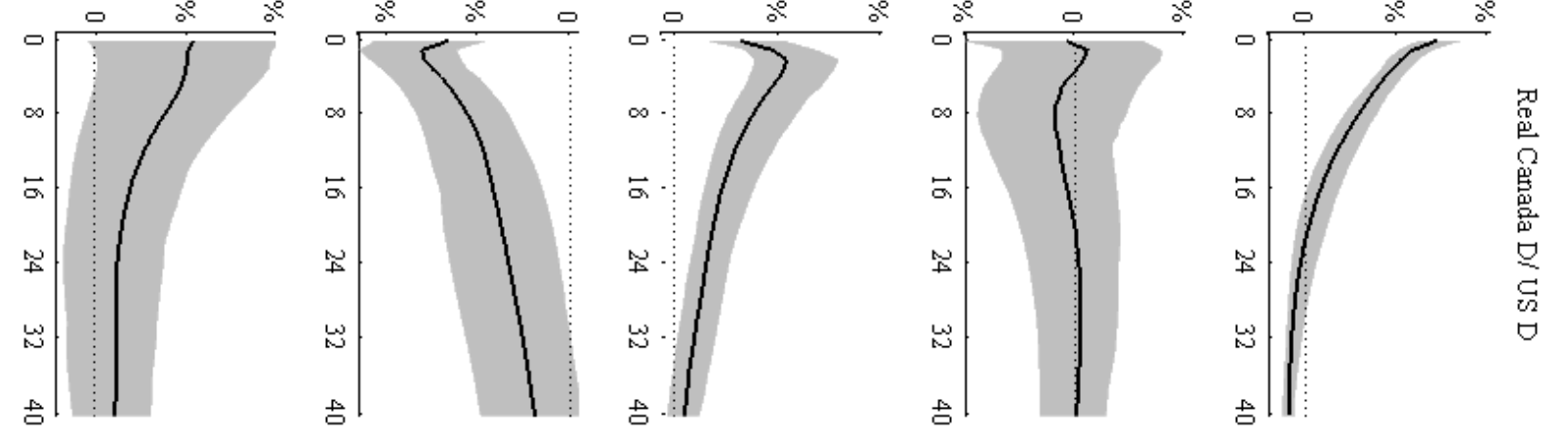


\section{TABLES}

Table 1: Unconditional Moments of the Data

\begin{tabular}{|c|c|c|c|c|c|}
\hline \multirow[b]{2}{*}{ Series } & \multicolumn{2}{|c|}{ Canada } & \multicolumn{2}{|c|}{ US } & \multirow{2}{*}{$\frac{\text { Model Canada Variable }}{\text { (Filtered Data) }}$} \\
\hline & Mean & $\underline{\mathrm{SD}}$ & Mean & $\underline{\mathrm{SD}}$ & \\
\hline Real Consumption Growth & 0.36 & 0.73 & - & - & $\Delta \hat{C}_{\mathrm{t}}$ \\
\hline Real Investment Growth & 0.32 & 2.55 & - & - & $\Delta \hat{I}_{t}$ \\
\hline Nominal Interest Rate & 1.40 & 0.77 & 1.17 & 0.56 & $\hat{R}_{t}$ \\
\hline CPI Inflation & - & - & 0.72 & 0.51 & $\hat{\pi}_{t}^{C P I}$ \\
\hline CPI Goods Inflation (T) & 0.47 & 0.79 & - & - & $\hat{\pi}_{H t}^{T}$ \\
\hline CPI Services Inflation (NT) & 0.75 & 0.43 & - & - & $\hat{\pi}_{t}^{N T}$ \\
\hline Import Price Inflation & -0.42 & 2.57 & - & - & $\hat{\pi}_{M t}^{T}$ \\
\hline Export Price Inflation & 0.12 & 3.21 & - & - & $\hat{\pi}_{H t}^{* T}$ \\
\hline Nominal Wage Inflation & 0.61 & 0.97 & - & - & $\Delta \widehat{w}_{t}+\hat{\pi}_{t}^{C P I}$ \\
\hline Depreciation of Can Dol/USD. & -0.20 & 2.97 & - & - & $\Delta \widehat{N e} x_{t}$ \\
\hline Demeaned Real Can Dol/USD & - & 12.47 & - & - & $\Delta \widehat{\operatorname{Re}} x_{t}^{C P I}$ \\
\hline
\end{tabular}

Note: The natural logarithms of all time series except the nominal interest rate are multiplied by 100 and hence all the numbers exhibited above can be interpreted as percentages. The $\mathrm{T}$ and $\mathrm{NT}$ in parentheses indicate 'tradables' and 'non-tradables' respectively. 


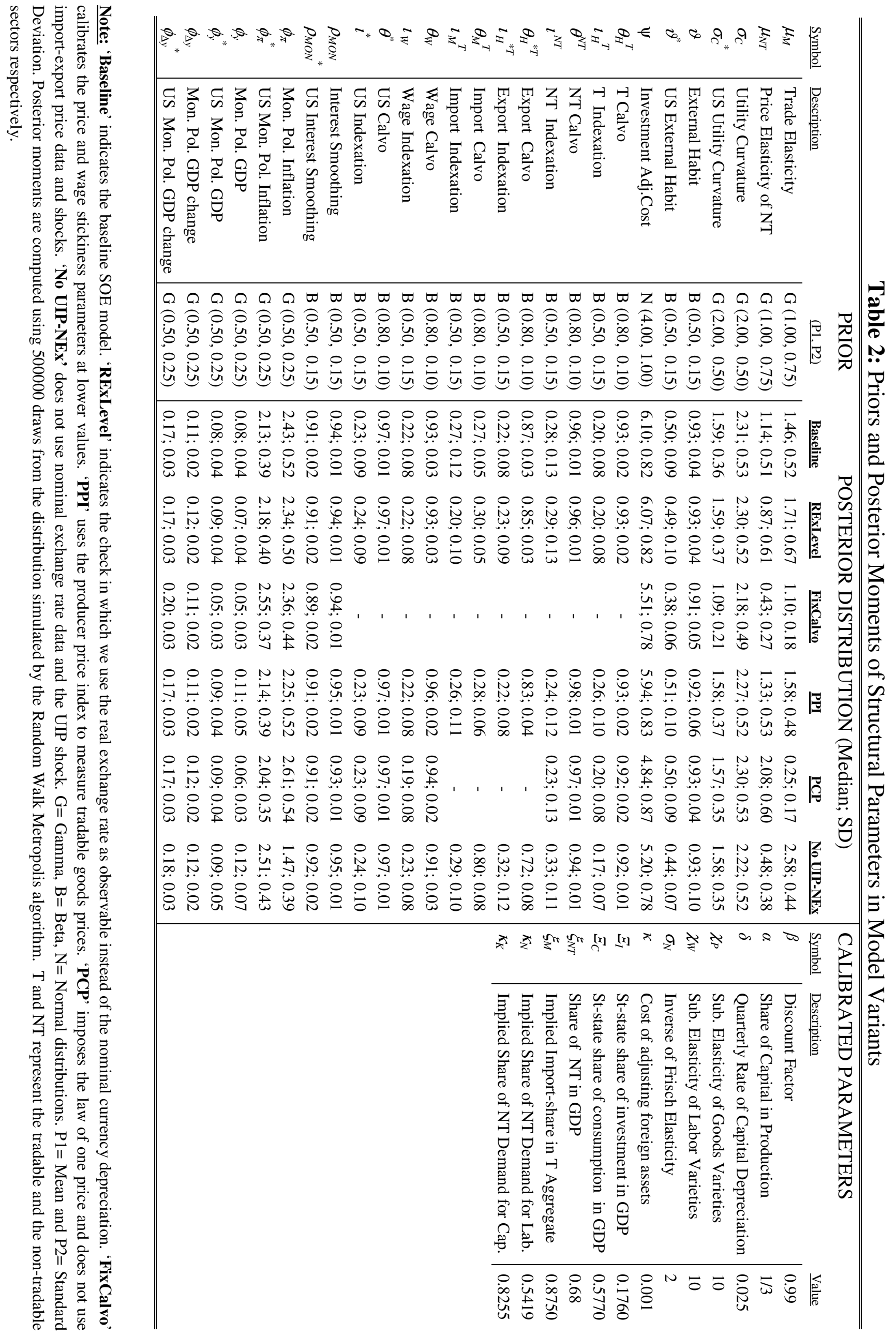




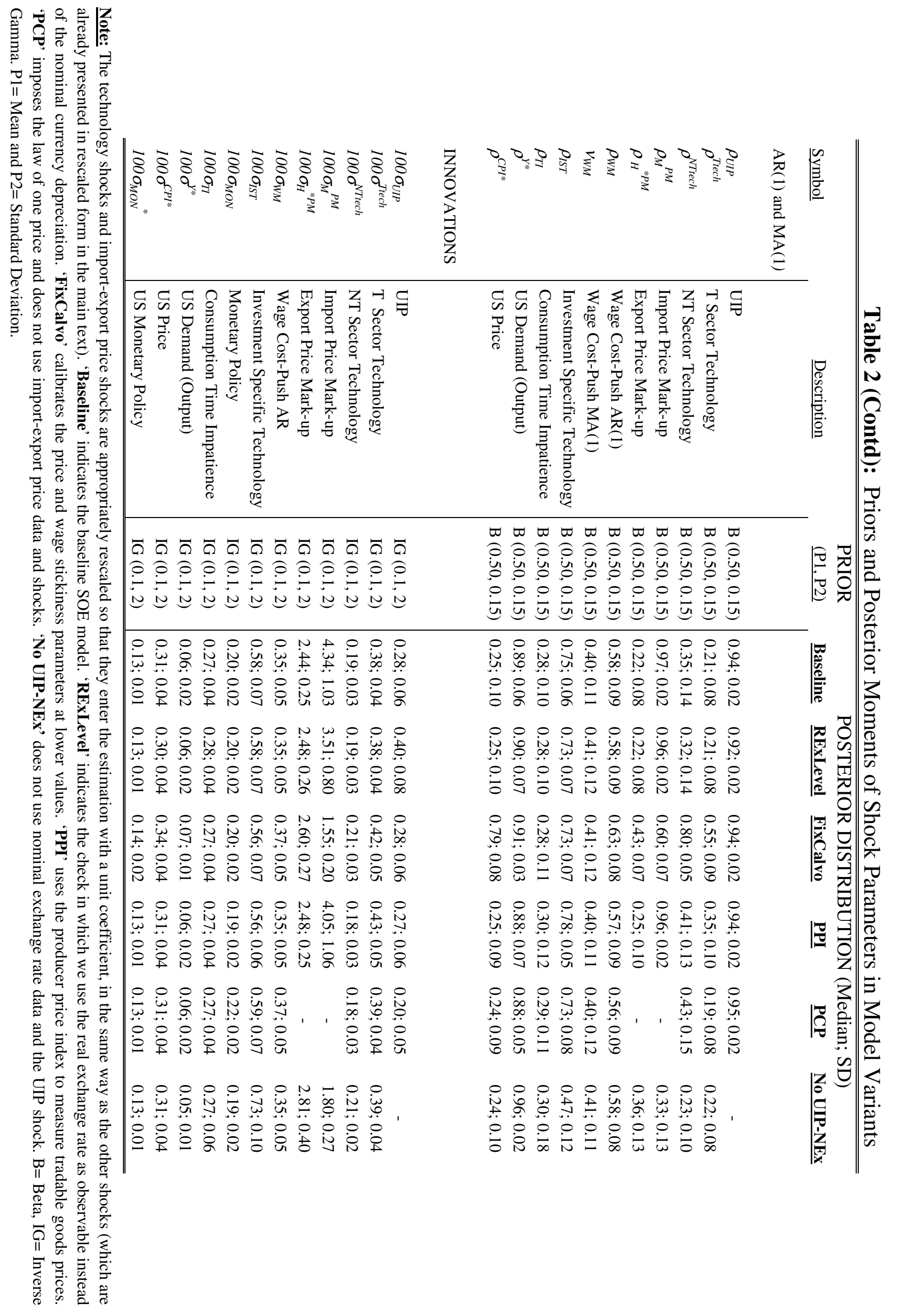




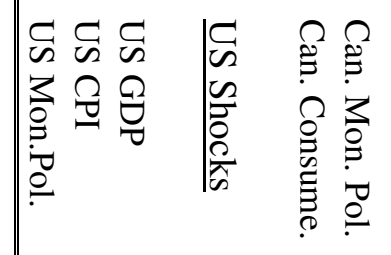

un

U

$\stackrel{\sim}{\sim} \sim$

D.

च.

(11)

귱융

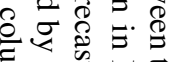

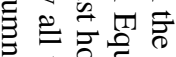

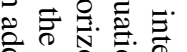

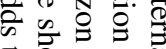

o

8 公

产

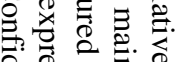

के

융ㄹㅇ

实宁家

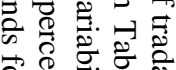

율

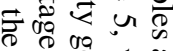

बृ

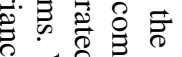

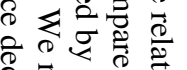

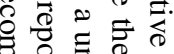

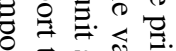

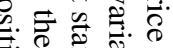

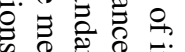

苛完令

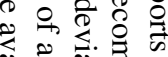

吾.

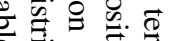

它司

$\overrightarrow{0}$ 东 $\cong$

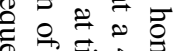

矿证

․ㅠ.

ठ유

के छ

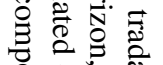

․

它节总

$8 \stackrel{\vec{E}}{\overline{0}} \overline{\mathrm{s}}$

융휴 훙

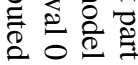

$\bar{\sigma}+\underset{\infty}{+\infty}$

$\circ N$

N

$\stackrel{0}{\infty}$

№v

$\omega-\omega$

ఫi

$\omega \omega$

$\stackrel{N}{N} \stackrel{\omega}{\omega} \stackrel{\omega}{\omega}$

$-\pi$

ĩ

$\stackrel{\infty}{\infty}$

$\circ N$

ने 요

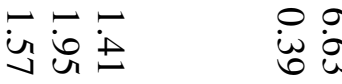

in

iñ

$\circ: 0$

웅요

$\circ 00 \quad 0$

웅

is

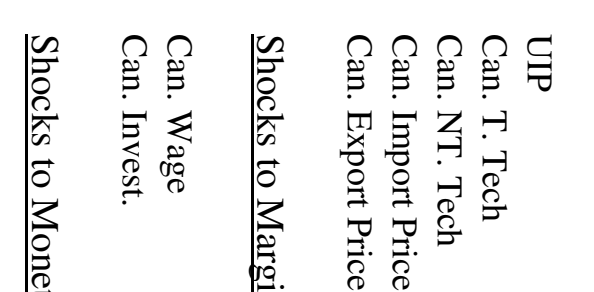

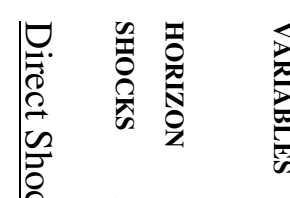

齐

Nㄴ.웅

앙

$\stackrel{\infty}{N}:$

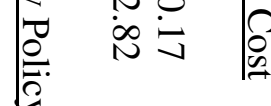

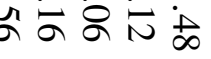

$+\omega \omega \circ$

そิ்

잉

ชิ

$+\infty+0 \hat{N}$

w。NNN

No

$\infty \stackrel{\sim}{+}$

$\omega \circ 0+9$

N

ํํㅇ

$\circ \circ \circ \infty$ นั

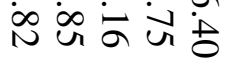

$\checkmark N O \sim \mathbb{\omega}$

6.

N

iู

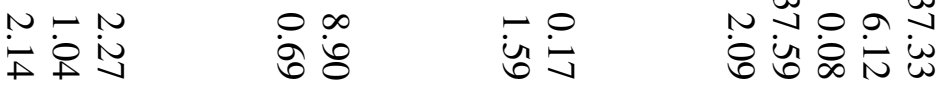

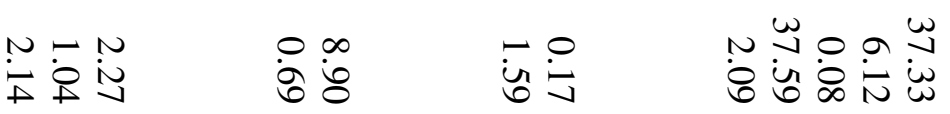

i్ర

w.

$\overrightarrow{\dot{\omega}} \ddot{\sim} \dot{i}$

i。 落

فํํ요요

w

iN

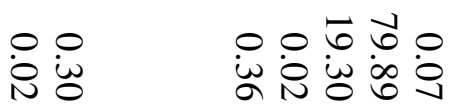

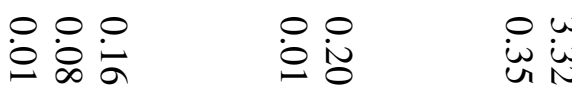

- o w U్

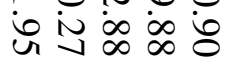

요 iั

- N w

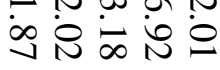

- ने०o पr

ir 겅ㅇํㅇ

岕少

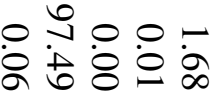

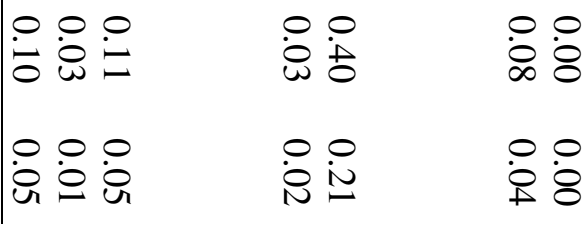

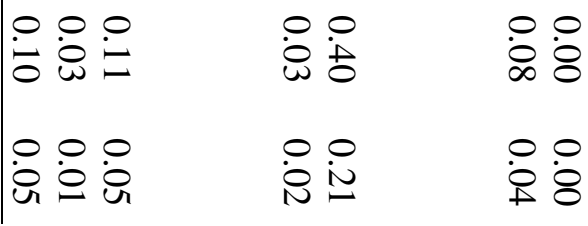

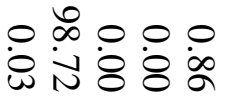

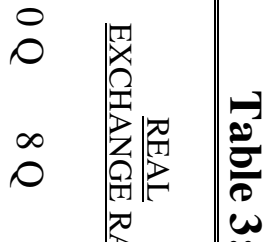

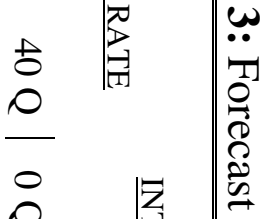

$\infty$

$\pi$

$\theta ?$

司

$\left.\begin{array}{ll}1 \\ 0\end{array}\right)\left[\begin{array}{l}\pi \\ 0\end{array}\right.$

$\stackrel{0}{0}$

$\infty$

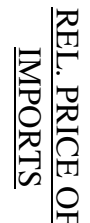

b

0
0
0

政

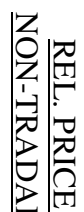

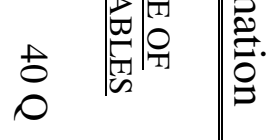

$\stackrel{0}{0}$

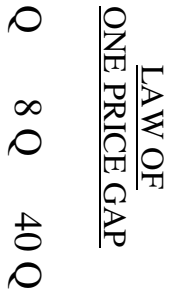




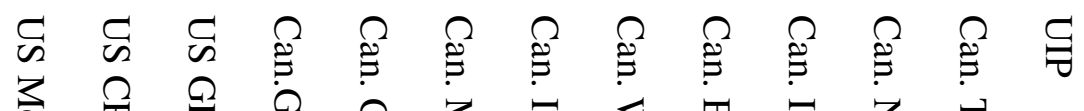

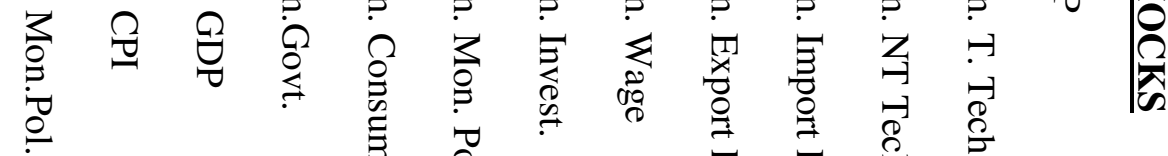
$\stackrel{0}{\circ}$

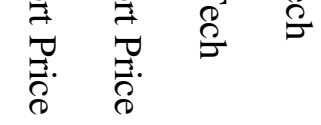

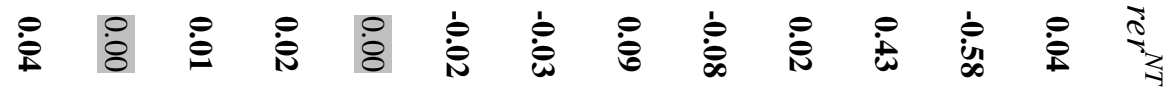

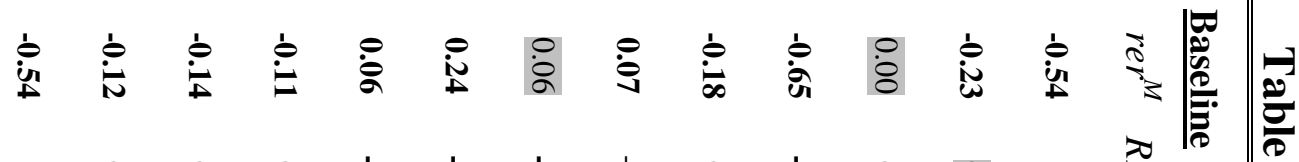
†

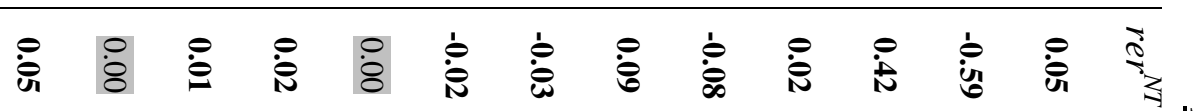

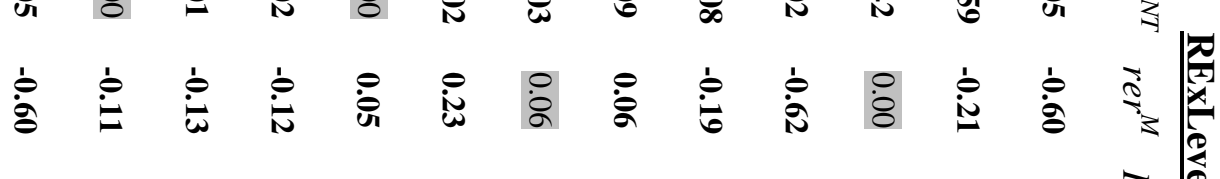

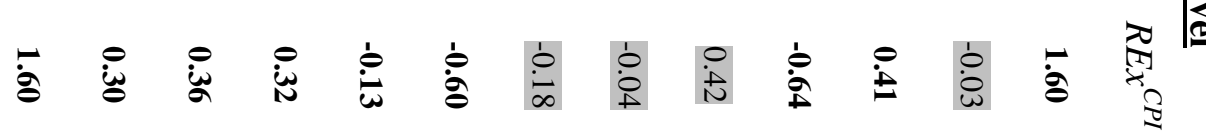
$\begin{array}{llllllllllllll}\dot{8} & \dot{8} & \dot{8} & \dot{8} & \dot{8} & \dot{8} & \dot{8} & \dot{8} & \dot{8} & \dot{8} & \dot{0} & \dot{0} & \dot{8} & \dot{0}\end{array}$

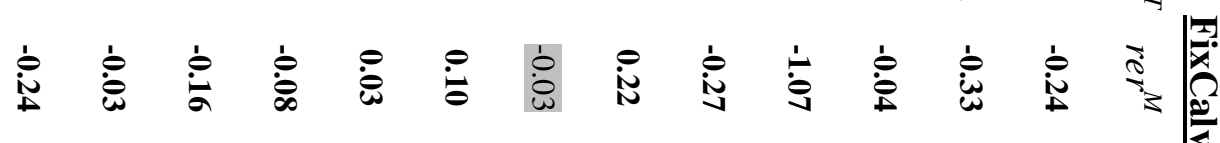

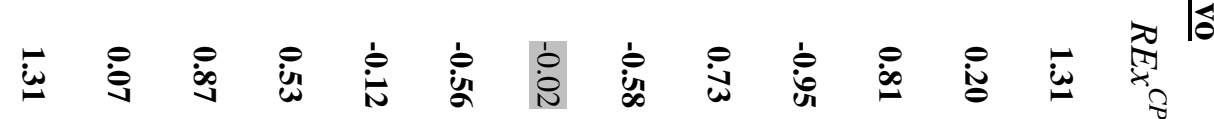
$\stackrel{+}{\circ}$

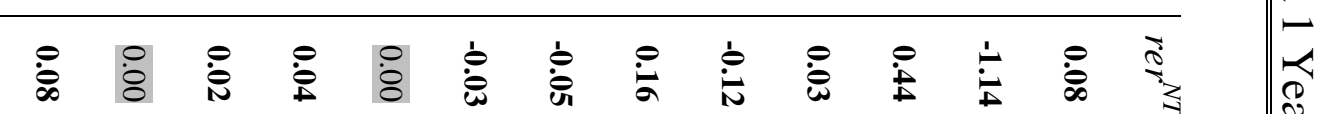

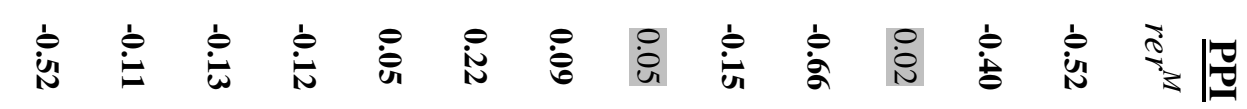

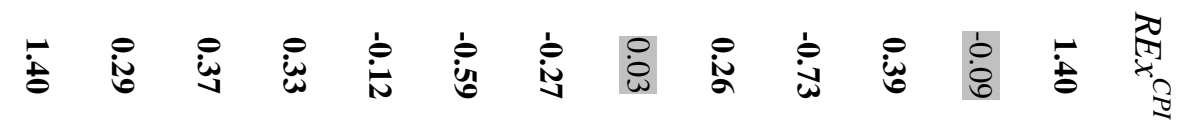

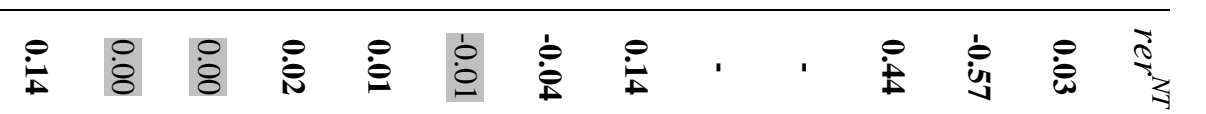

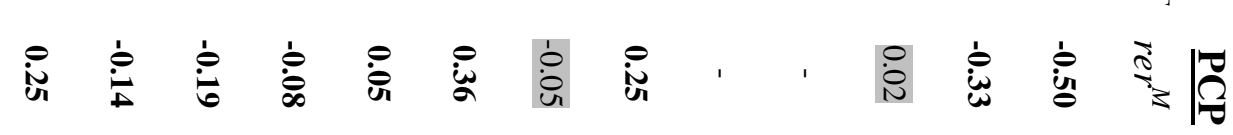
i

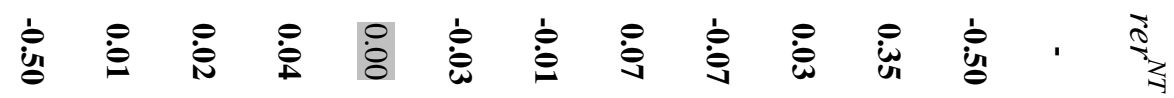

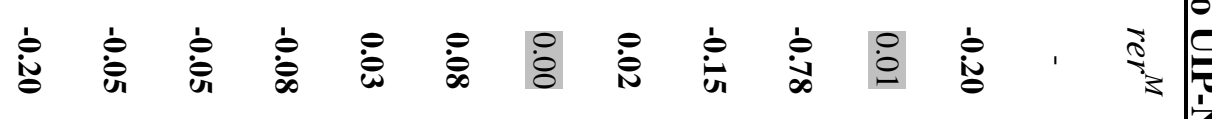

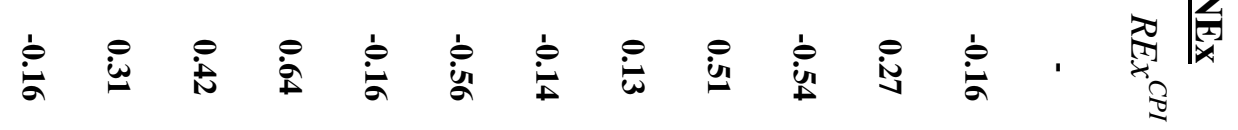


离

ธत्र

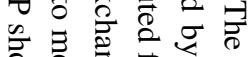

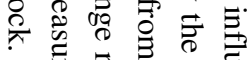

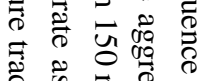

के कै

\%

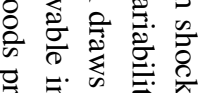

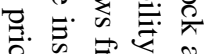

के

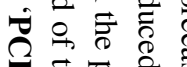

च ₹

క气 Ð

政

क एँ:

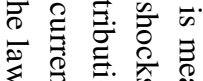

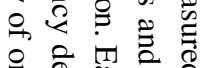

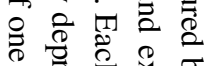

可

ते 气

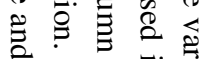

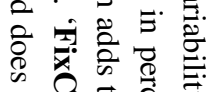

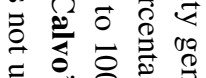

范

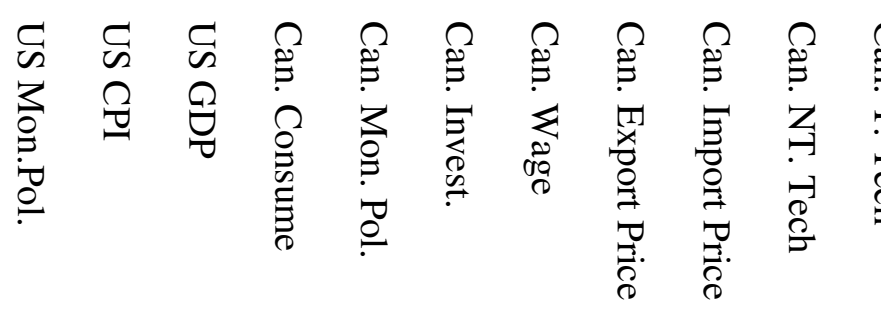

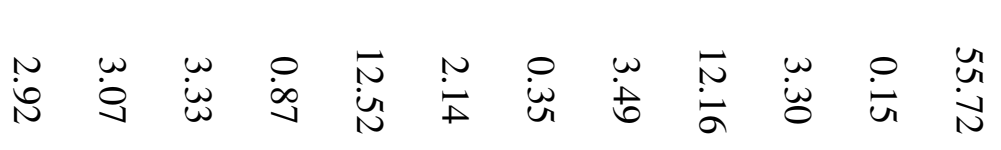

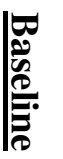

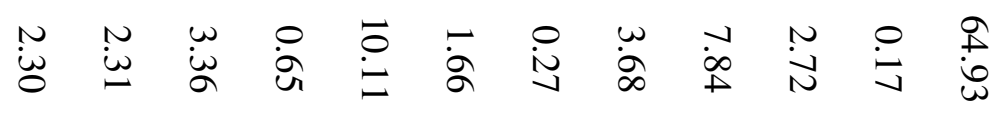

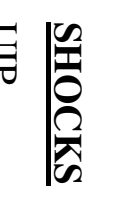

|

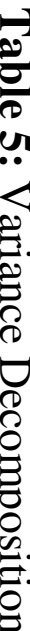

声䜦

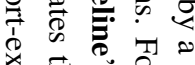

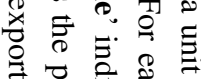

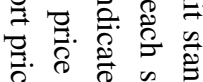

त.

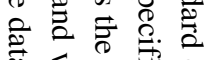

ॠ

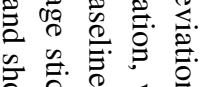

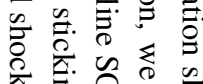

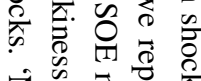

ż

氜产官

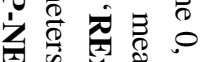

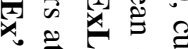

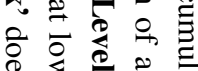

品产

을 芯

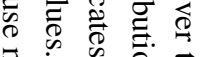

ठ휭

昰官

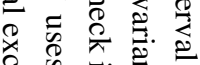

O

产

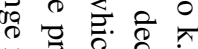

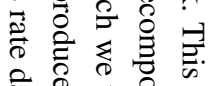

产 $\stackrel{0}{0} 0$.

है छे

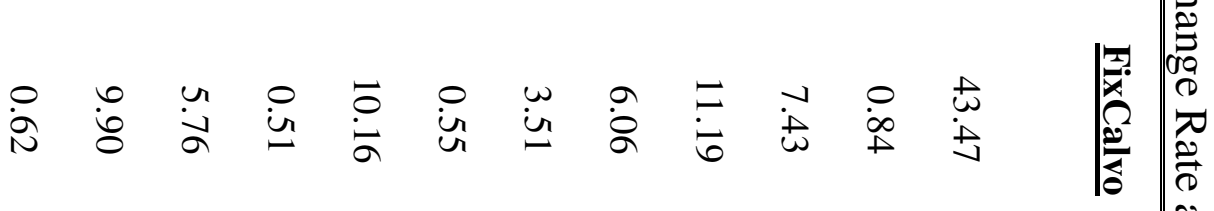

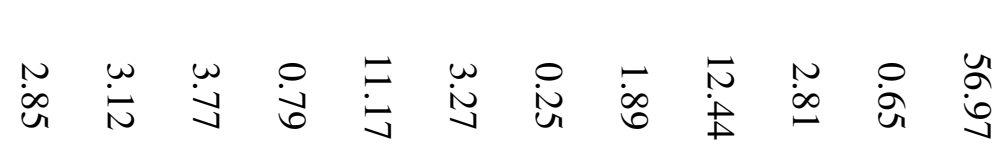

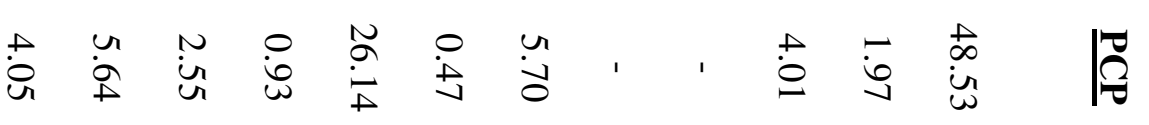

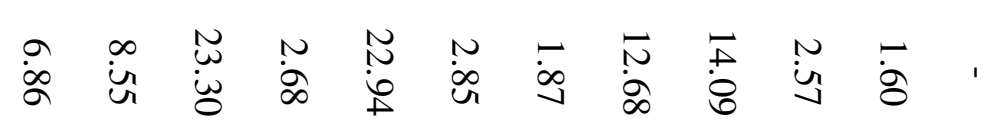

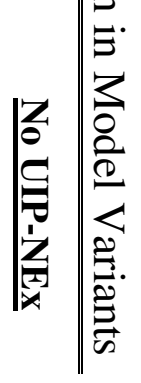

